\title{
AS SEDIÇÕES DE 1831 EM PERNAMMUUCO.
}

\section{APRESENTAÇÃO}

Estudando os acontecimentos políticos do estado de Pernambuco no ano de 1831 - por sinal um dos mais agitados de nossa história, devido, principalmente, à abdicação do primeiro Imperador - com as revoltas ou motins que nele tiveram lugar, achamos imprescindivel escrever uma introdução em que déssemos aos leitores uma visão suscinta dos principais acontecimentos da província, desde o alvorecer do século XIX. Tal atitude foi determinada pelo fato de participarem dos acontecimentos de 1831 várias figuras que já haviam participado de episódios anteriores e de julgar necessário, para se compreender as atitudes tomadas naquele ano, a atuação dos mesmos em situações anteriores. Também fazemos esta recapitulação porque consideramos a primeira metade do século XIX, uma época de muita agitação, na qual eram freqüentes as revoluções e conspirações que ensanguentavam constantemente $o$ nosso estado. Dentre muitas, podemos assinalar algumas de maior importância como a Conspiração dos Suassunas, em 1801, a revolução de 1817 , a atuação da Junta de Goiana em prol da Independência, em luta contra Luís do Rêgo, que já havia sido vítima anteriormente de um atentado, a deposição de Gervásio Pires Ferreira, os motins de Pedroso, em 1823, a Confederação do Equador, em 1824, a revolta dos Roma, em 1829, o motim de maio de 1831, a Setembrizada, a Novembrada, a Abrilada, a Guerra dos Cabanos e, finalmente, a Revolução Praieira, que encontrou no Prof. Amaro Quintas competente historiador.

Como o objetivo do nosso estudo é o motim de maio de 1831 , conseqüente a chegada, aqui, da notícia da abdicação, a Setembrizada e a Novembrada, que se deram respectivamente em setembro e novembro dêsse ano, faremos um ligeiro retrospecto dos acontecimentos anteriores a êste e passaremos depois a estudar cuidadosamente êstes motins, interpretando-os à luz das principais causas de ordem econômica, política e social, que os determinaram. Para assim procedermos, passámos muito tempo na Biblioteca Pública do Estado, a pesquisar grande quantidade de manuscritos antigos, de 
correspondência de autoridades de então e os inúmeros jornais da época.

Na parte referente à introdução, que compreende o estudo dos acontecimentos anteriores a 1830 , não fizemos pesquisas e nos limitamos a utilizar a grande bibliografia sôbre aquêle período, a qual citamos nơ fim da mesma.

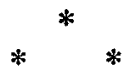

\section{INTRODUÇÃO}

Em fins do século XVIII, chegava a Pernambuco o naturalista e médico Manuel de Arruda Câmara que, na Europa, estudara a princípio em Coimbra e depois em Montpelier, as ciências naturais. Na França, ao lado de sua especialidade, estudou as doutrinas dos filósofos liberais e, certamente, pertenceu à maçonaria, convencendo-se de que era necessário tornar o Brasil uma nação livre e elevar cultural e socialmente a sua grande população negra. Tal idéia ainda o dominava em 1810 quando, às vésperas da morte, escreveu uma importante carta ao Padre João Ribeiro, na qual dizia "Com a monarquia ou sem ela deve a gente de côr ter ingresso na prosperidade do Brasil" (1) carta esta em que, ao lado de disposições testamentárias, dava ordens de interêsse político.

Arruda Câmara teve no Brasil várias incumbências científicas e deixou inúmeros trabalhos preciosos sôbre botânica e mineralogia, mas sua maior glória advém, talvez, de haver fundado em Itambé, vila fronteiriça entre Pernambuco e Paraíba, o célebre Areópago que foi certamente a primeira associação secreta fundada no norte do país com o fito de propagar as idéias liberais que, vitoriosas na França e nos Estados Unidos, empolgavam todos os que combatiam ou não se conformavam com o absolutismo monárquico então defendido pelos inimigos de Napoleão Bonaparte. Aí, no Areópago, passou Arruda Câmara a propagar as idéias novas de que se abeberara na Europa e conseguiu reunir em tôrno de si um grupo pequeno, mas selecionado, de adeptos. Entre êstes, aponta Maximiliano Lopes Machado (2), o Capitão André Dias de Figueiredo e os padres Antônio Felix Velho Cardoso, José Pereira Tinoco,

(1). - Pereira da Costa, Dicionário Biográfico de Pernambucanos Célebres. Recife, 1882, pág. 642 .

(2). - Maximiliano Lopes Machado, Introdução à História da Revolução de Pernamco em 1817, pelo Doutor Francisco Muniz Tavares. Recife, 3a. edição, 1817. 
Antônio d'Albuquerque Maranhão e João Ribeiro Pessoa. A êstes, acrescenta Donatello Grieco (3), os irmãos Francisco de Paula, Luís Francisco de Paula e José Francisco de Paula Cavalcanti de Albuquerque.

A semente plantada por Arruda Câmara não demorou a florescer, pois já em 1801, era denunciada pelo comerciante José da Fonseca Silva Sampaio, uma conspiração chefiada pelos irmãos Francisco e Luís Francisco de Paula Cavalcanti de Albuquerque, os quais em entendimentos com o terceiro, José, que se achava em Lisboa, tramavam uma revolução em Pernambuco, contando com o apôio de outros povos americanos e do próprio Napoleão. A denúncia foi apresentada ao Juiz de Fora, Antônio Manuel Galvão e, logo após, eram presos dois denunciados, pelo capitão Sebastião José Frazão de Andrade e Silva e recolhidos incomunicáveis à Fortaleza das Cinco Pontas. As recomendações feitas ao Comandante da Fortaleza eram descriminadas em uma portaria, estabelecendo que não deixasse que os mesmos se comunicassem entre si ou com qualquer pesso: de dentro ou de fora da mesma, podendo apenas receber visita do cirurgião ou médico e esta mesma, na presença do dito comandante ou do seu imediato e receber o "sustento para os ditos" devendo colocar na porta da prisão sentinelas escolhidas entre "os soldados de melhor nota". Enquanto isto eram sequiestrados os bens dos presos, excetuando-se as partes de suas espôsas e passava-se a fazer a devassa, na qual foram ouvidas 80 testemunhas.

$O$ inquérito nada apurou contra os denunciados, diz-se, que em consequiência da compra do escrivão Fonseca que, por quatrocentos mil réis, "abafou" uma carta comprometedora. Parece ter sido intermediário neste subôrno o Padre José Laboreiro, amigo do Bispo Azeredo Coutinho, em cujas mãos correram "rios de dinheiro" (4).

Finalmente, nada havendo sido apurado, foram os irmãos Cavalcanti de Albuquerque libertados no dia 26 de maio de 1802, e levantado o seqüestro sôbre os seus bens e, embora continuassem a manter seus princípios e idéias liberais, a ponto do engenho Suassuna, de propriedade de Francisco de Paula tornar-se uma das chamadas Academias, passou êste, dissimulando as suas idéias, a gozar das boas graças dos governadores e do Rei e a receber títulos e honrarias como as que se seguem: o hábito de Cristo em 1804, e a 28 de abril do mesmo ano, foi nomeado Capitão de Ordenanças

(3). - Donatello Grieco, Napoleão e Brasil. Rio. Civilização Brasileira S. A., (4). - Maximiliano Lopes Machado, op. cit. prosperidade do Brasil" (1) carta esta em que, a olado de disposi- 
da Freguesia de Jaboatão, para no ano seguinte, ser confirmado no pôsto de Capitão-mor das Ordenanças de Olinda e, finalmente, obter em 1808, o Fôro de Fidalgo Cavaleiro da Casa Real. Assim, ia o chamado Corchel Suassuna, como era conhecido, se enchendo de títulos e mercês conferidos pelo. Rei, enquanto em sua propriedade, em sua casa, propagava as idéias liberais na chamada Academia que, com a do Paraíso, dirigida em Recife pelo Padre João Ribeiro Pessoa, propagaria as idéias divulgadas por Arruda Câmara, no Areópago.

Os dirigentes das duas Academias - a do Paraíso e a Suassuna -, auxiliados pelos seus adeptos, iam sempre propagando as idéias liberais e preparando uma elite revolucionária, saída principalmente da burguesia das vilas mais importantes, do clero e das incipientes profissões liberais, para fazer a revolução que estalaria imprevistamente em 1817. Devemos salientar que apesar do desaparecimento do Areópago, continuou a ser grande a ascendência de Arruda Câmara sôbre seus discípulos e que o mesmo se mantinha ao par dos novos iniciados, pois em carta ao Padre João Ribeiro, escrita em 1810, dizia êle:

"tenham todo o cuidado no adiantamento dos rapazes Francisco Muniz Tavares, Manuel Paulino de Gouveia, José Martiniano de Alencar e Francisco de Brito Guerra" (5).

Notamos, entretanto, que o proselitismo maçônico penetrou pouco no seio da classe dos grandes proprietários rurais, tornando-se mais intenso entre os intelectuais, ao mesmo tempo que fazia algum desenvolvimento entre comerciantes abastados, nascidos no Brasil. E' interessante notar que Pernambuco, como já salientou Gilberto Freyre, teve uma formação acentuadamente patriarcal, aristocrática e que em quase todo o período colonial havia apenas senhores e escravos. Poucos eram os indivíduos existentes entre estas duas classes que formavam o germe de onde sairia uma classe média. No início do século XIX ainda era esta a situação econômico-social da Província, pois haviam os grandes proprietários rurais, na maioria senhores de engenho, ao lado dos quais se destacavam também os grandes plantadores de algodão, enriquecidos com os melhores preços alcançados por êste produto no mercado internacional, em consequiência da guerra de 1812-1813 entre os Estados Unidos e a Inglaterra, que desejavam combater os comerciantes portuguêses, seus credores e inimigos, mas que temiam uma revo-

(5). - Pereira da Costa, op. cit. 
lução liberal, porque pela própria situação em que viviam, identificavam a autoridade que tinham em suas propriedades com a do rei absoluto do país. Também temiam que do liberalismo dos mações viesse a abolição da escravatura, o que muito receavam, porque era o braço escravo essencial à prosperidade da agricultura tropical que possuíam. Estes, em sua maioria, se mostraram infensos às idéias liberais e à maçonaria, embora houvesse alguns que formassem exceção, como os Suassunas, os irmãos Carvalho Paes de Andrade - Manuel e Francisco - e outros mais. A maioria, porém, mostrou-se sempre contrária às idéias liberais. $\mathrm{Na}$ cidade de Olinda e nas vilas de Goiana e Recife, sobretudo nesta, que era o pôrto, desenvolvia-se bastante o comércio e já se formava uma burguesia comercial urbana, constituída em sua maioria de portuguêses, mas entre êstes encontravam-se algumas figuras nascidas no Brasil, como Cruz Cabugá e Gervásio Pires Ferreira que, desejando a independência, se deixaram imbuir pelas novas idéias, pelas entã's chamadas idéias "francesas". Por estas idéias também se deixou influenciar grande parte da oficialidade nascida no Brasil, por ver que era preterida nas promoções, em benefício de oficiais portuguêses nem sempre mais capazes e leais do que êles. Mas, o maior contingente maçon era constituído por padres, porque o foco das idéias liberais foi o Seminário de Olinda, após a organização dada ao mesmo pelo notável Bispo Azeredo Coutinho, do qual saíram figuras como o Padre João Ribeiro, o Padre Tenório, Padre Venâncio $H$. de Resende, para citar apenas os principais.

Tão grande era o número de padres maçons, de padres liberais, que já se disse que a revolução de 1817 , foi uma revolução de padres. A metade da população constituída por escravos, por pretos e mulatos livres, não tomou conhecimento das novas idéias pregadas, embora por êles tivesse especial atenção, o naturalista Arruda Câmara.

\section{II}

Um fato contribuiu muito para a maior propagação das idéias liberais em Pernambuco, o caráter do governador Caetano Pinto de Miranda Montenegro. Êste homem que era tolerante e não confiava na fôrça das idéias, achava que os maçons se divertiam, conspirando, e não tomou providências para evitar que as Academias Suassuna e do Paraíso, fizessem proselitismo. Até autoridades, como o Ouvidor de Olinda, Antônio Carlos Ribeiro de Andrada Machado e Silva, em suas correições, procurava atrair as pessoas com quem convivia, às suas idéias. Talvez seu próprio secretário, o mineiro José Carlos Mayrink da Silva Ferrão, conspirasse, se "divertisse" 
com os maçons. O que é verdade, porém, é o fato de que a Capitania esteve durante o seu longo govêrno, em estado deplorável, as obras públicas paralisaram-se e as já construídas não eram conservadas, a segurança inđividual não tinha a menor garantia e, dizem, certa vez o próprio governador foi vítima de gatunos. À noite êle jogava com amigos, em Palácio, enquanto os maçons discutiam os princípios liberais que desejavam aplicar ao Brasil e a soldadesca esperava receber o miserável sôldo que, há meses, não lhes era pago, apesar de devido. Entusiasmados com a falta de vigilância do Govêrno, os liberais conspiravam abertamente, chegando até a enviar emissários para coordenar o movimento que se faria aqui, com o que deveria surgir nas províncias vizinhas. Para isto estiveram na Bahia, Domingos José Martins e Domingos Teotônio Jorge, enquanto que o Ceará foi atraído à causa, pelo Coronel Francisco de Paula Cavalcanti de Albuquerque.

Mas, em março de 1817 , a situação tornou-se tão grave, que recebendo uma denúncia, resolveu o Govêrno determinar a prisão dos principais implicados. Este fato faria rebentar prematuramente a revolução que há tempo vinha sendo preparada, mas rebentar inesperadamente, quando seus agentes não tinham traçado os planos necessários à vitória. E, a 6 de março, quando procedia à prisão do Capitão José de Barros Lima, e Leão Coroado, foi o Brigadeiro Manuel Joaquim Barbosa de Castro, assassinado, pelo mesmo, passando os revolucionários a dominar o quartel e, logo após, graças à impetuosidade do Tenente Antônio Henrique Rebêlo, os bairros de Santo Antônio e Recife, como relata muito bem Monsenhor Muniz Tavares. A covardia do Governador, que recolheu-se à Fortaleza do Brum e logo se entregou, contribuiu para que os revolucionários dominassem fàcilmente a situação e organizassem o primeiro govêrno republicano que houve no país. Dêste govêrno participavam váries classes, através de seus representantes, como: o clero, na pessoa do Padre João Ribeiro Pessoa, a magistratura, na pessoa do Dr. José Luís de Mendonça, as fôrças armadas, na pessoa do Capitão Domingos Teotônio Jorge, o comércio, na pessoa de Domingos José Martins e a agricultura, na do Coronel Manuel Correia de Araújo, senhor do engenho Camaragibe. Do Conselho do Govêrno participavam, entre outros, o comerciante Gervásio Pires Ferreira, que teria grande influência em nossa política, alguns anos depois, o ouvidor Antônio Carlos, um dos maiores oradores do país e Antônio de Morais e Silva, filólogo e senhor do engenho Muribeca. Francisco de Paula recebeu o comando das fôrças republicanas.

Pouco tempo durou a jovem República, apesar de contar com a adesão da Paraíba, do Rio Grande do Norte e das Alagoas que, 
então, pertencia a Pernambuco. A esperada adesão baiana malogrou com a prisão e fusilamento, por ordem do Conde dos Arcos, do Padre Roma e a do Ceará também malogrou com a prisão to seminarista José Martiniano de Alencar, pelo Ten-Cel. Filgueiras. Os senhores de engenho, apesar da adesão de Manuel Correia de Araújo e do entusiasmo despertado pela fácil vitória dos revolucionários, não aderiram ao movimento. A maioria permaneceu neutra, para logo após, quando compreendeu que a situação não era tão favorável aos rebeldes, passar a hostilizar o movimento. Eles temiam a libertação dos seus escravos, embora o govêrno revolucionário lhes garantisse que assim não procederia, para não ferir o direito de propriedade. E no fim, o próprio Manuel Correia de Araújo, que só aderira ao movimento depois dêle vitorioso, passou-se para o lado realista e lutou contra os seus companheiros. Também Antônio de Morais e Silva, cuja simpatia pela causa real era notória, não participou das reuniões do Conselho para que fôra nomeado e, dizendo-se doente, permaneceu no seu engenho até que a revolta fôsse sufocada.

Não pretendemos estudar, em seus detalhes, a revolução de 1817, pois Oliveira Lima, Muniz Tavares, Maximiliano Lopes Machado (6) e Amaro Quintas (7) já o fizeram; queremos apenas ressaltar, nesta ligeira introdução ao estudo de acontecimentos que the sucederam, como se portaram os revolucionários na hora da desdita, quais os que permaneceram fiéis às suas idéias e os que procuraram apenas salvar a vida.

Não foram poucos os heróis; homens como o Padre João Ribeiro, como Domingos José Martins, como Domingos Teotônio Jorge, como o Leão Coroado, como o Capitão Antônio Henrique, souberam se portar como estoicismo diante da morte e dar um exemplo zo povo e aos tiranos. Outros, porém, tiveram comportamento diverso; assim, José Carlos Mayrink da Silva Ferrão, que alcançaria elevados postos durante o Primeiro Reinado, conseguiu dar uma demonstração de maestria em oportunismo, pois, de Secretário de Caetano Pinto de Miranda Montenegro, passou a secretário do govêrno republicano e, após a vitória dos realistas, foi protegido por Luís do Rêgo, grande algoz dos pernambucanos. Interessante é que, enquanto êle recebia proteção dêste famigerado general português, o seu auxiliar, por ocupar o cargo de auxiliar de secretário do govêrno republicano, era condenado a morrer na fôrca, o Padre Tenório. De traição, foi a atitude do representante da agricultura

\footnotetext{
(6). - Notas de Oliveira Lima e Maximiliano Lopes Machado à Histótia da Revoluçáo de Pernambuco de 1817, op. cit.

(7). - Amaro Quintas, $A$ Gênese do Espirito Republicano em Pernambuco e a revolução de 1817 (Contribuição ao Estudo da História da República). Tese de concurso, Recife, 1939 .
} 
no govêrno, Manuel Correia de Araújo, que a 6 de março, estava com os realistas, nas poucas medidas tomadas para conter a rebelião, a 7 , estava com os republicanos, a ponto de ser eleito para participar do govêrno pelos mesmos constituído e, logo após, passou a conspirar com outros senhores de engenho, para restaurar o poder real e, finalmente, colaboraria com as tropas reais na restauração. Bem dúbia, salientemos, foi a atitude dos irmãos Francisco de Paula e Luís Francisco de Paula; a respeito, é interessante transcrever o seguinte trecho de Oliveira Lima (8):

"Relatou-me o Sr. Conselheiro João Alfredo Correia de Oliveira, cuja memória é tão notável quanto o senso de estadista, que mais de uma vez lhe contou o Visconde de Camaragibe, que o pai, o coronel Suassuna, partira do engenho para o Recife, com as suas ordenanças, ao ter notícia do movimento, dando todos vivas ao Rey".

Mas no Recife êle lembrou-se das idéias pregadias em sua casa - Academia de Suassuna - e pactuou logo com os republicanos, ganhando a confiança dos companheiros que o viam como um dos expoentes das idéias liberais e tornou-se o general de divisão dos mesmos. Comandou as tropas que foram enviadas contra o Marechal Cogominho e como não fôsse atendido em seus apelos, pelos senhores de engenho do Cabo, que eram em sua imensa maioria realistas; perseguiu-os e destruiu as instalações do engenho Utinga. Desbaratado, voltou ao Recife e quando Domingos Teotônio Jorge abandonou a praça com a fôrça de que dispunha, permaneceu como principal autoridade da cidade, junto com o irmão que comandava a Fortaleza do Brum; mal os retirantes atingiam Paulista, aclamou o Rei e libertou o Marechal José Roberto, a quem entregou o govêrno. Compactuou com os realistas, entregando-lhes, sem um tiro, a praça que lhe havia sido confiada. Seria realmente liberal e republicano, o hoje glorificado Coronel Suassuna? Como êle, Antônio Carlos, que estando em Limoeiro ao rebentar a revolução, correu para o Recife, a fim de participar da direção da mesma e que em cartas aos irmãos e a Menezes Drumond, seu amigo, se mostrava jubiloso com os sucessos de Pernambuco e adepto da República; ao ser prêso verberou as idéias revolucionárias, alegando ter colaborado com a revolução, sob coação. Leia-se a história do glorioso evento de 1817 e notar-se-á que Gervásio Pires Ferreira foi uma figura dúbia durante todos os acontecimentos, como seria incapaz de tomar uma atitude definida ao ocupar o govêrno de Pernambuco, nos sucessos de 1821 e 1822. A revolução de

\footnotetext{
(8). - Oliveira Lima, Notas à História da Revolução de Pernambuco em 1817 ,
op. cit.
} 
1817, a primeira revolução brasileira em favor da independência., teve os seus heróis, mas teve também os seus oportunistas e os seus. traidores, como tôdas as revoluções.

Viria depois o terrível consulado de Luís do Rêgo.

\section{III}

Luís do Rêgo, general que se distinguira na guerra peninsula:, chegando ao Recife com tropas disciplinadas e bem experimentadas, tratou de manter a ordem e foi, apesar dos preconceitos oriundos. de sua formação, um pouco realista ao examinar a revolução de. 1817. Assim, para êle, os chefes da revolução podiam ser divididos em dois grupos: o dos homens maus, desonestos, que trama-ram e executaram a mesma, visando o próprio interêsse, e o dos homens idealistas que entusiasmados com uma idéia, para êle errada, fizeram a revolução. Verberava muito mais ao Govêrno quedeixou que se fizesse a propagação das idéias liberais, não evitando em tempo a eclosão do movimento que foi, como reconhece, extemporâneo; e ainda ao Brigadeiro Manuel Joaquim Barbosa de Castro, por não saber executar as ordens recebidas, como sejam: prisão dos oficiais suspeitos, seus comandados, insultando-os antes de executar as medidas. Mas, absolutista e fiel ao seu Rei, era favorável a um castigo exemplar aos revolucionários e se muitos dêles não foram executados, em Pernambuco, devem êstes fatos ao desentendimento surgido entre Luís do Rêgo e o Presidente da Alçada, Desembargador Bernardo Teixeira, o que provocou a transferência desta Côrte e dos prisioneiros para a Bahia e o retardamento no julgamento dos mesmos. Este retardamento faria com que muitos. dos chefes mais implicados, como Antônio Carlos, José Mariano e Pedroso, escapassem à fôrca. Conhecendo a belicosidade dos pernambucanos e a necessidade de fortalecer a sua posição na Província, assim tratou Luís do Rêgo de recrutar os mesmos e dar-lhes. instrução militar, tendo o cuidado de entregar sempre aos portuguêses os postos de comando de maior responsabilidade. Prevenia-se contra uma surprêsa como a de 6 de março. A população vivia desgostosa e submissa; quase tôdas as pessoas tinham um parente ou um amigo prêso, na Bahia, a sofrer os maiores vexames, sendo por isso, muitas vêzes, olhada com desconfiança pelos novos dominadores. Vários heróis já haviam marchado para a fôrca, como acontecera com Domingos Teotônio Jorge, Antônio Henriques Rebêlo e o Padre Tenório. Na Bahia, outros revolucionários haviam pago com a vida o sonho de uma pátria livre.

Súbito, chegou a notícia da vitória da revolução constitucionalista do Pôrto e, após, a anistia para os republicanos que se achavam. 
presos na Bahia. Compreendendo que a éra do absolutismo estava finda, ou achando melhor compactuar com as novas idéias que alcançavam vitórias, ou ainda, com o fim de dirigir a revolução que se processava, evitando que os pernambucanos a fizessem, tratou Luís do Rêgo de mostrar-se fiel aos novos princípios e ganhar a confiança dos habitantes da terra; passou a reintegrar os implicados na revolução de 1817 , recém-chegados dos cárceres da Bahia, nos postos que antes ocupavam. Deu demonstração de possuir idéias democráticas, esquecendo que para aqui viera com o fito de dominá-las, como nocivas ao govêrno absolutista a que servia; quando falaram na organização de uma Junta Governativa, êle foi o primeiro a apoiar a idéia e organizar uma com base na representação das classes - princípio que dominara na formação do govêrno republicano de 1817. Visando evitar a separação entre os dois reinos - Brasil e Portugal -, tratou de organizar, como o fêz a 31 de março, uma Junta Constitucional Governativa, composta de elementos que the mereciam confiança e tendo como representante da classe militar, o Marechal de Campo Luís Antônio Salazar Moscoso, da magistratura, o ouvidor geral Antero José da Maia e Silva e o Dr. Antônio de Morais e Silva, representando o comércio, Joaquim José Mendes e Antônio da Silva Companhia e a agricultura, José Camelo Pessoa de Lacerda. Claro que dispondo da tropa que comandava, Luís do Rêgo continuou governando a capitania e a Junta a êle submetida, ora aumentava ora diminuia o número dos seus componentes, conforme aconselhassem os interêsses do Çapitão General (9).

Reconhecida a Junta pelas Côrtes, tratou Luís do Rêgo de promover o juramento da Constituição e mandou proceder às eleições dos deputados às mesmas Côrtes.

Entretanto, os revolucionários de 1817 não se sumbetiam aos caprichos de Luís do Rêgo e, enquanto êle organizava, no Recife, - seu simulacro de govêrno constitucional, alguns egressos dos cárceres baianos, como Mena Calado e Manuel Clemente, se reuniam no engenho Cangaú, em Nazaré da Mata, de propriedade de Joaquim da Cunha Souto Maior e conspiravam, estendendo essa conspiração até a Paraíba.

Sabedor do que se passava, determinou o Capitão General forte perseguição aos seus opositores, o que provocou um atentado contra sua vida, perpetrado por João Souto Maior, a 21 de julho. Ferido, êle passou vários dias recolhido à casa do Dr. Morais e Silva, enquanto determinava a prisão de inúmeros pernam.

(9). - Oliveira Lima, O Movimento da Independência 1821-1822. São Paulo. Editôra Proprietária Companhia Melhoramentos de São Paulo, 1922. 
bucanos, julgados por êle coniventes no atentado e dêles mandando 42 para as prisões de Lisboa e 13 para degrêdo em Fernando de Noronha. Entre os prisioneiros, em sua imensa maioria inocentes, encontravam-se Francisco Paes Barreto, Morgado do Ca-bo e futuro Marquês do Recife, Francisco do Rêgo Barros, futuro: Conde da Boa Vista e Sebastião do Rêgo Barros, que seria ministro da guerra durante o Império.

Durante a doença de Luís do Rêgo, iniciou-se em Nazaré o. movimento nacionalista com o levantamento do senhor do engenho Tamataúpe, Coronel de Milícias Manoel Inácio Bezerra de. Melo, que auxiliado por Mena Calado e pelos proprietários da redondeza, marchou sôbre Goiana, ocupando a vila, apesar da resistência oposta pelo Juiz de Fora. Constituiu-se, então, a famosa Junta de Goiana, composta pelo Dr. Francisco de Paula Gomes dos Santos, Joaquim Martins da Cunha Souto Maior, Antônio Máximo de Souza, Manuel Silvestre de Araújo, João Carlos de Melo e Albuquerque, José Camelo Pessoa de Melo, Padre Manuel dos Reis Curado, Bernardo Pereira do Carmo, Capitão José Vitoria-no Delgado de Borba Cavalcanti de Albuquerque e Capitão José Joaquim Coelho Lopes de Castro. Como primeira medida, intimaram Luís do Rêgo a retirar-se do Recife e entregar-lhes o govêrno. Diante da intimação, o General titubeou e a sua Junta propôs à Junta de Goiana um acôrdo que não foi aceito sob a alegação de que esta era a única Junta legal por ter o apôio da maioria das. Câmaras da capitania, enquanto aquela tinha apenas o apôio das Câmaras da vila do Recife e da Capital - Olinda. Recusdo o. acôrdo, resolveram as Juntas enviar tropas em punição uma da outra, por se considerarem mùtuamente ilegais.O encôntro entre as duas fôrças se deu em Igarassú, mas não houve batalha porque: os soldados brasileiros treinados por Luís do Rêgo e comandados: por portuguêses, em sua maioria desertaram para o lado dos na-. cionais, enquanto o pequeno grupo que se mantivera fiel, bateu em. retirada.

Avançaram então os de Goiana até Beberibe; Luís do Rêgo. dispôs-se à resistência e fortificou-se na cidade, pondo a mesma em pé de guerra, enquanto esperava que the enviassem reforços, da. Bahia. Os de Goiana estabelecendo em Beberibe o seu quartel general, trataram de colocar o Recife e Olinda sob cêrco, estendendo suas linhas desde essa cidade até a povoação dos Afogados. Neste. terreno teria Luís do Rêgo de se defender, mas não chegando reforços, nem desejando as partes ardentemente a luta, iniciaram,. em outubro, negociações visando um acôrdo. Enviou a Junta do. Recife a Beberibe uma comissão formada por Gervásio Pires Fer.- 
reira, que para tal incumbência se ofereceu, Luís Francisco de Paula Cavalcanti de Albuquerque, futuro visconde de Suassuna e que participara, com o pai, - Coronel Suassuna - da revolução de 1817, e um representante da Junta da Paraíba, João de Araújo Cruz, que aqui se achava à procura de um entendimento entre os dois governos existentes em Pernambuco. As conversações iniciadas em 5 de outubro, foram terminadas com um acôrdo que estabelecia ficar a Junta do Recife com autoridade nesta vila e na Capital e a de Goiana em todo o interior até o dia 26 do mesmo mês e que, neste dia, na Sé de Olinda, se realizaria uma eleição, da qual participariam representantes de tôdas as Câmaras da $\mathrm{Ca}$ pitania e elegeriam a nova Junta. Essa, então, teria autoridade em todo o território pernambucano. Compreendendo que não podia mais dirigir o movimento constitucionalista em Pernambucn, Luís do Rêgo partiu em um navio francês para a Europa, no dia 26 de outubro, o mesmo dia em que se procedia à eleição da nova Junta. Os pernambucanos respiraram, compreenderam que o grande inimigo da causa nacional, considerando-se vencido, sem fôrças, abandonava o nosso território. Neste dia foi eleita a nova Junta que era formada por Gervásio Pires Ferreira, presidente, Felipe Nery Ferreira, Cônego Dr. Manuel Inácio de Carvalho, Joaquim José de Miranda, Antônio José Vitoriano Borges da Fonšeca e o português Bento José da Costa. Foi escolhido para seu secretário, o Padre Laurentino Antônio Moreira de Carvalho.

Era assim a Junta dominada pela ala mais moderada dos revolucionários de 1817. Ela era formada pelos que só haviam aderido àquela revolução, quando ela estava vitoriosa e que ao verem que esta vitória era efêmera, passaram a tomar atitudes que pudessem obter o perdão do Rei. Entre êles, salientava-se o presidente Gervásio Pires Ferreira que, vitorioso o movimento de 1817, fizera ao govêrno republicano grandes doações e fôra escolhido para o Conselho Consultivo do mesmo, mas não só compa. receu às reuniões como nos últimos dias da revolta colocou-se na cama, alegando doença, para se eximir de maiores culpas. $\mathrm{Na}$ prisão afirmava que colaborara com o govêrno revolucionário, sob coação e que procurara sempre sabotar a ação do mesmo. Na realidade, era êste homem muito hábil mas extremamente vacilante e não possuía uma capacidade de decisão capaz de o tornar um chefe valoroso de um govêrno que ainda iria enfrentar sérias situações. Êsses defeitos são logo notados por quem lê a sua biografia escrita pelo Conselheiro Antônio Joaquim de Melo, com o fim de o elogiar e de o defender. Felipe Nery Ferreira, também. liberal, participou como eleitor da assembléia que escolheu o go- 
vèrno republicano de 1817 , e sob as ordens do mesmo foi "juiz ordinário do crime e da polícia da vila e têrmo do Recife" (10), sendo após a derrota, prêso até o ano de 1821, apesar de haver exercido aquêle cargo com muita moderação e de ser por isto elogiado por todos.

Gervásio Pires Ferreira inicia, assim, com a Junta que presidia, um govêrno que iria enfrentar as mais difíceis situações. Creio, após a leitura do livro do Conselheiro Antônio Joaquim de Melo, $\mathrm{ccm}$ as copiosas notas e documentos transcritos, que o novo presidente desejava conseguir a independência de Pernambuco, sob a forma republicana. Temia acompanhar a política do Rio de Janeiro, por não confiar nos Andradas, que se tornariam seus inimigos, e por não acreditar que o príncipe D. Pedro fôsse levado a proclamar a independência, principalmente porque êle constantemente afirmava a sua lealdade ao pai. Parece ainda que Gervásio Pires Ferreira tinha alguma esperança que as Côrtes portuguêsas tivessem uma atitude correta em relação ao nosso país e havendo jurado fidelidade às mesmas e ao Rei, não queria romper êste juramento. Causava-lhe ainda desconfiança, alguns atos do Príncipe Regente que não eram de sua competência, mas de poder legislativo e, como liberal, não podia apoiar essa atitude. Em oficios a êle dirigidos chegou a afirmar isto, naturalmente empregando uma linguagem muito respeitosa. Acreditamos que nessas dúvidas debatia-se o Presidente, enquanto as tropas portuguêsas eram uma constante ameaça aos sentimentos nacionais e as massas populares eram trabalhadas contra êle, pelos seus inimigos, alguns dêles, como Meneses Drumond, para aqui enviados pelo próprio José Bonifácio.

De posse do Govêrno, cuidou logo Gervásio Pires Ferreira de afastar de Recife as fôrças portuguêsas aqui existentes, temendo que houvesse choques entre as mesmas e as nacionais. Outras que vieram depois, êle impediu que desembarcassem, e que foi uma medida de grande alcance, uma vez que evitou que se desse no Recife, o que aconteceu na Bahia, com o General Madeira. Consentiu, entretanto, no desembarque do Brigadeiro José Correia de Melo, português, que havia sido nomeado para o cargo de Governador das Armas pelas Côrtes. Claro que reconhecendo a soberania portuguêsa, não poderia êle impedir êsse desembarque, como fizera das tropas, sob a alegação de temer desordens.

Entre os seus auxiliares colocou elementos que seriam, algum tempo depois, conhecidos por abraçarem princípios republicanos e que já haviam participado da revolução de 1817, como Manuel

(10). - Pereira da Costa, op. cit. 
de Carvalho Paes de Andrade e o Padre Venâncio Henriques de Resende, o que nos leva a crer que em sua indecisão, em suas vacilações, houvesse um pouco de astúcia, através da qual procurava êle manter Pernambuco afastado não só de Portugal, como do grupo que desejava a independência do país, adotando-se a forma monárquica de govêrno. Isto não é uma afirmativa, apenas mera conjectura, porque ainda nesta época os republicanos mais exaltados, se eram acusados de tal, negavam pelos jornais esposar tais idéias, temendo a reação do público, inegàvelmente pouco simpático à idéia republicana.

Ao receber ordens emanadas do Príncipe Regente e julgadas ilegais ou contrárias às Côrtes, Gervásio Pires Ferreira não negava - a execução das mesmas, protelava-se o mais possível. Assim aconteceu com a ordem para a eleição dos representantes de Pernambuco no Conselho de procuradores e com outras de menor importância. Quando se encontrava $\mathrm{Em}$ situação difícil, levava a discussão para o seu aspecto legal ou constitucional e dispondo de grande poder de argumentação, procurava confundir o seu competidor.

Mas José Bonifácio compreendendo a situação em que se achava e a necessidade de um apôio real de Pernambuco à sua causa - independência com monarquia - enviou para o Recife uma pessoa de sua confiança, Antônio Meneses de Vasconcelos Drumond, que aqui chegando, procurou levantar o povo, promovendo uma reunião da Câmara do Recife, sob presidência do Juiz de Fora, a qual comparecerem as mais graduadas autoridades minitares e eclesiásticos exigindo da Junta o reconhecimento do Príncipe D. Pedro como chefe do Poder Executivo no Brasil, independente de delegação do poder português, embora sujeito às Côrtes e ao Rei de Portugal. A Junta ainda tentou discutir o assunto, mas coagida por grande massa popular, apoiada pela tropa, foi forçada a capitular, comprometendo-se a enviar ao Rio de Janeiro uma deputação presidida por Felipe Nery Ferreira. Mas continou em suas vacilações e só depois de muito tempo, a 2 de julho de 1822 partiu - essa deputação, chegando ao Rio a 19. Apesar do apôio agora hipotecado a $\mathrm{D}$. Pedro, do compromisso assumido, a Junta continuou .em suas vacilações, pois relutou muito em mandar proceder à eleição dos deputados à Assembléia Constituinte do Rio de Janeiro, convocada por D. Pedro, alegando necessitar fazer antes um recenseamento da população. A 3 de agôsto, porém, a turba forçou-a a nova decisão neste sentido, apoiada mais uma vez pela fôrça armada. Era assim a Junta, tendo a frente seu presidente e orientador, levada a fôrça a apoiar a solução andradina. Finalmente o :povo e a tropa mostravam-se cansados diante da indecisão da 
Junta, que só tomava as mais difíceis atitudes, sob coação, e como desejava José Bonifácio que orientara um movimento em tal sentido (11), ela foi deposta pelo inquieto Capitão Pedroso a 17 de setembro, portanto 10 dias após a proclamação da independência. Gervásio Pires Ferreira, desgostoso, embarcou no mesmo dia para o Rio de Janeiro, sendo na Bahia entregue ao General Madeira que o remeteu prêso para Lisboa. Esta prisão talvez tenha evitado que êle participasse do movimento de 1824, que chefiado po: Manuel de Carvalho Paes de Andrade, seu amigo, tentou separar o Nordeste do Império sob a forma republicana de govêrno.

\section{IV}

Deposta a Junta presidida por Gervásio Pires Ferreira, foi organizada outra da confiança do Ministério Andrada, que poderia, assim, cooperar melhor com o govêrno do Rio de Janeiro. Era composta principalmente de senhores de engenho e pessoas ligadas aos grandes proprietários, os quais, por esta mesma condição, tinham uma orientação política conservadora e viam na monarquia uma boa solução. Eram seus membros (eleitos a 23 de setembro): Afonso de Albuquerque Maranhão, presidente, José Mariano de Albuquerque Cavalcanti, secretário, Francisco Paes Barriano de Albuquerque Cavalcanti, secretário, Francisco Inácio Ribeiro de Melo, Francisco de Paula Cavalcanti de Albuquerque e João Nepomuceno Carneiro da Cunha, vogais. Os dois últimos renunciaram antes mesmo de tomar posse. Pedroso, o truculento capitão, substituiu o tenente-coronel Aleixo José de Oliveira, no cargo de Governador das Armas, sendo logo após, promovido a sargentomor e depois a tenente-coronel. A Junta chamada dos "matutos", por ser composta em sua maioria de senhores de engenho, nascera sob péssima proteção, a do truculento capitão Pedroso (12). Êste capitão que, por ser mulato, tinha em 1823 grande prestígio entre a população pobre, em sua maioria composta de homens de côr, era extremamente violento e em 1817 já dera provas disto. A 6 de março daquele ano assistiu à morte do Brigadeiro Barbosa e, solidarizando-se com 0 ato do Leão Coroado, passara-se logo para a rua com alguma tropa, cabendo a êle ordenar à mesma que atirasse no Tenente-Coronel Alexandre Tomás, ajudante de ordens e enviado do Capitão General, quando êste se aproximava do quar-

(11). - Antônio Joaquim de Melo, Gervásio Pires Ferreira. Recife. (2 vols.) 1895.

(12). - Alfredo de Carvalho, Os Motins de 1823, in "Revista do Instituto Arqueológico e Geográfico de Pernambuco. 
tel dos rebeldes. Durante a revolução destacou-se por suas atituđes violentas, chegando até a fuzilar sem julgamento e sem autorização do govêrno, alguns desertores, quando as tropas reais vitoriosas iniciavam a aproximação do Recife. Prêso, escapou à morte devido à anistia concedida pelas Côrtes que não o atingiu em parte, pois, acusado de assassinato, foi condenado ao degrêdo na Ásia e, quando seus companheiros regressaram livres para Pernambuco, êle foi remetido para Portugal. Lá foi perdoado e voltando a Pernambuco derrubou, como salientamos, a Junta de Govêrno, graças às intrigas - arquitetadas por Bernardo José da Gama, futuro Visconde de Goia: na, que aqui prestava serviços ao Apostolado (13).

Governador das Armas, passou êle a fazer constantemente exigências à Junta e a imiscuir-se nos negócios de competência desta, sem atender nem consultar seus membros. Também a fraqueza da .Junta era manifesta, pois, se ali havia pessoas que achavam deverse impedir as arbitrariedades de Pedroso, havia também quem, dosejando participar com maior importância no govêrno e sabendo que êle dispunha da fôrça, o cortejava e procurava utilizá-lo contra os demais membros. Era seu grande amigo Paula Gomes; os choques -entre Pedroso e a Junta foram se sucedendo e embora estivesse consagrado, teòricamente, o princípio da submissão do poder Militar ao - Civil, a Junta era constantemente desrespeitada pelo Governador - das Armas que nela contava com o apôio de Paula Gomes e de José Mariano. A Junta tentando livrar-se de Pedroso, pediu a $D$. Pedro I a nomeação de um novo Governador das Armas e êle desejando continuar na função, procurou um pretexto para forçar uma renúncia dos membros da Junta que obedeciam à orientação do Morgado do Cabo, a fim de que o govêrno ficasse com seus amigos. Aproveitando um simples caso disciplinar, o do Tenente Taveira, ameaçou a Junta e esta cedeu, concordando na prisão do mesmo. Foi completa a desmoralização do govêrno porque a única falta do Tenente Taveira, alegada por Pedroso, foi a de ter-se afastado do seu pôsto, em Pôrto das Galinhas, a chamado da Junta, sem o seu conhecimento. Aconselhada pelo Intendente de Marinha, Manuel de Carvalho, a Junta esboçou uma reação, logo dominada por Pedroso, que fàcilmente ocupou a cidade. Os membros da Junta, temerosos, : retiraram-se para os seus engenhos, Paes Barreto, para o Velho, - Afonso de Albuquerque Maranhão, para o Guerra, Manuel Inácio - e José Mariano procuraram o norte da província, enquanto Paula - Gomes, no subúrbio Poço da Panela, esperava o desenrolar dos acontecimentos. Abandonada a vila, ficou Pedroso como seu senhor

(13)..-Ibidem. 
na tarde de 22 de fevereiro de 1823 (14). A 23 convidou Paula Gomes a voltar a cidade e passou a estudar com êle os meios que deveriam ser empregados para forçar a renúncia do Morgado do Cabo e de Afonso Albuquerque Maranhão.

A 24, Pedroso impaciente por não ter obtido a renúncia dos seus inimigos, oficiou às Câmaras de Olinda e Recife, convidando-as a se reunirem para a organização de uma nova Junta. A de Olinda não se dignou a responder. A do Recife, o fêz, inesperadamente, concitando o povo à reação e convindando-o para restabelecer o govêrno legal. Foi uma aittude corajosa tomada pelos seus membros - Francisco Xavier Pereira de Brito, Manuel Francisco dos Santos Mendonça, Vicente Ferreira dos Guimarães Peixoto e Bento José da Costa Júnior - pois incorrer nas iras do Governador das Armas, no momento senhor absoluto do Recife, era muito perigoso. Mas a coragem dêstes homens contagiou os habitantes e o povo compreendeu que precisava lutar contra a ilegalidade. Os próprics partidários do chefe rebelde, temeram pela sorte da rebelião e no dia seguinte, 25 , parte da tropa chefiada pelo Capitão Francisco José Martins, abandonou a cidade com o fim de juntar-se ao govêrno deposto. Paes Barreto e Afonso de Albuquerque não eram homens para a ocasião, pois em vez de iniciarem a contra-revolução e de organizarem os seus para retomar o Recife, permaneceram nos seus engenhos, cercados pela parentela enorme, do primeiro, e de seus dependentes, esperando reforços. Não estavam de forma alguma à altura dos Membros da Câ. mara do Recife e só trataram de voltar à vila, quando convidados a negociar, pelo próprio Paula Gomes, que a 26 , notara ir se eclipsando a estrêla de Pedroso. A frente de grande multidão marchou Paes Barreto para o Recife, juntou-se a 28 às tropas que lhe eram fiéis E ocupou no mesmo dia o Forte das Cinco Pontas e a Boa Vista. Pedroso não se dispôs a lutar, dirigiu-se à Câmara e passou - cargo de Governador das Armas ao Coronel José Inácio Alves Ferreira, sendo prêso ainda na Casa da Câmara, no dia 29, pelo Intendente de Marinha. Os amigos de Pedroso entrincheirados no Largo do Erário, atual Praça da República, ainda resistiram até - dia 1 de março, quando desanimados, baquearam. A devassa instaurada, quase não se aplicou, pois, apesar de haver sido pronunciado, Paula Gomes, com um pequeno afastamento, continuou a participar da Junta e Pedroso enviado prêso ao Rio de Janeiro. foi sôlto pouco depois, graças às intrigas e pedidos do futuro Visconde 'de Goiana.

(14). - Ibidem. 
Claro que a Junta por pouco tempo se manteria no poder. Ninguém mais confiava nela, pois, após se submeter a todos os caprichos do Governador das Armas, que dela dependia, foi deposta pelo mesmo e só reassumiu o poder porque a Câmara do Recife soube reagir e a Pedroso faltou espírito de luta. Não soube ela defender os seus direitos e os seus membros ficaram conhecidos como fracos, incapazes de uma atitude enérgica nos momentos decisivos. Por isto ela foi, logo após, substituída por outra, da qual era presidente, Manuel de Carvalho Paes de Andrade, o homem que prendera Pedroso; secretário, o poeta José da Natividade Saldanha e Governador das Armas, o Coronel José de Barros Falcão de Lacerda, que voltara engrandecido da Bahia, onde se distinguira como comandante da fôrça pernambucana que se batera contra o General Madeira. Voltavam a dominar o espírito de 1817 e os homens que possuíam idéias republicanas. Tinha $c$ novo govêrno $c$ apôio inconteste da população citadina, embora fôsse olhado com desconfiança pelos homens do campo que suspeitavam ser o novo presidente republicano e, talvez, abolicionista.

A notícia da dissolução da Assembléia Constituinte, por D. Pedro, indignou os pernambucanos e foi verberada pela imprensa liberal, tendo à frente o Typhis Pernambucano de Frei Caneca. A imprensa defendia a idéia de se considerar como não terminado o mandato dos deputados pernambucanos à Assembléia dissolvida, o que foi aceito pela Câmara de Olinda (16), assim como a recusa de discutir o projeto de Constituição elaborado pelo Imperador. Maior ainda foi a inquietação, quando se soube que $D$. Pedro nomeara presidente da província, a Francisco Paes Barreto, Morgado do Cabo. Esperava D. Pedro que êste homem merecesse o apôio da população porque nascera em Pernambuco e nessa província era possuidor de vários engenhos, descendendo, até de João Paes Barreto, um dos primeiros colonizadores, companheiro de Duarte Coelho e criador do Morgadio que Paes Barreto desfrutava. Paes Barreto, porém, não era simpatizado na província, pois, homem muito rico e convencido de sua nobreza, vivia muito distante do povo. Embora houvesse participado da revolução de 1817 , no cárcere da Bahia, nas horas de infortúnio, procurava afastar-se dos seus companheiros mais humildes, procurando conviver apenas com os mais nobres e ricos. Depois da anistia, demonstrava estar inteiramente convertido à monarquia, e como elemento

(15). - Tobias Monteiro, História do Império. Rio de Janeiro, 1.0 vol. F. Briguiet \& Cia., 1946 . 
reacionário às idéias de Gervásio Pires, participou da Junta chamada "Govêrno dos Matutos". Nesta Jun'ta, como vimos anteriormente, apesar de contar com a maioria dos membros, talvez devido ao prestígio proveniente de sua fortuna, demonstrou ser um fraco administrador e um homem sem energia. Afastado da Junta, esperavam os pernambucanos que êle não mais desejasse o. govêrno e fôsse administrar seus imensos latifúndios. Por esta razão sua nomeação foi hostilizada pelas Câmaras e Manuiıl de Carvalho comunicou ao Imperador que por esta razão deixava de lhe dar posse, propondo que êle nomeasse um homem que merecesse a confiança da população da província.

Tentando uma conciliação, nomeou o Imperador Josẻ Carlos Mayrink da Silva Ferrão que, amedrontado, não aceitou 'o cargo. Realmente, naquela ocasião ninguém pior indicado do que Mayrink, para o cargo de Presidente; êle não era pernambucano e aqui chegara como secretário do Capitão-General Caetano Pinto de Miranda Montenegro e, casando com uma pernambucana, se radicara no Recife. Era um homem sem nenhuma coragem e que aderia a quantos governos aparecessem, contanto que não o incomodassem. Assim, de secretário de Caetano Pinto, em 1817, êle passou a secretário do govêrno revolucionário e, após a vitó ria real, a secretário do Almirante Rodrigo Lobo. Como o presidlente da Alçada, Desembargador Bernardo Teixeira, quisesse prendê-lo, foi protegido e, dizem, escondido, por Luís do Rêgo, mas depois foi prêso e anistiado. Nas ocasiões difíceis, para não tomar uma decisão perigosa, êle usava do pretexto de se dizer doente e assim fêz, para se justificar de não poder assumir o govêrno da Província, quando os dois partidos, o republicano de Paes de Andrade e o monarquista de Paes Barreto, se degladiavam. Novas cartas foram enviadas ao Imperador e os partidários de Paes Barreto, impacientes, deram um golpe, e chefiados por Lamenha Lins e pelo Major Seabra, aprisionaram Manuel de Carvalho. A prisão foi feita pelo Capitão Francisco da Rocha Paes Barreto, auxiliado pelo Tenente Antônio Lins Caldas. O primeiro era irmão e o segundo cunhado do Morgado do Cabo, o que indica a conivência do mesmo com o golpe. No dia seguinte o Presidente foi libertado, graças a pronta ação do Major Soares Carne-viva e, assumindo o govêrno, preplarava-se para reagir contra seus afoitos inimigos, quando Paes Barreto resolveu retirar-se com os seus partidários para as Alagoas, a fim de esperar a ajuda imperial. Não desmentiu suas tradições, retirou-se, evitou a luta, não se arriscou enquento não dispôs de fôrças muito numerosas para combater o seu maior inimigo. 
Em abril de 1824, Taylor, com alguns vasos de guerra, por ordem do Imperador, determinou a Paes de Andrade que deixasse o govêrno, mas êste não obedieceu. Foi então decretado o bloqueio do pôrto do Recife. Começava a luta. Logo após, corria o boato de que Portugal enviaria uma expedição recolonizadora an Brasil e D. Pedro para melhor defender sua Côrte (o Rio de Janeiro), determinou a volta de Taylor. Paes de Andrade aproveitando a oportunidade, lançou proclamações ao povo declarando que $\mathbf{D}$. Pedro o abandonava quando se esperava um ataque português $e$ logo após, a 2 de julho, lançava uma proclamação separando Pernambuco do Brasil e convidando as províncias do norte a se unirem a êle para formar uma nova República, a Confedłeração do Equador. Para animar seus partidários, passou a tomar providências em favor da república nascente, convocando uma Assembléia Constituinte que deveria se reunir no antigo Palácio do Govêrno de Olinda, preparou um projeto de Constituição, suspendeu - tráfico de escravos, o que iria desgostar os senhores de engenho, e criou uma nova bandeira.

A atitude de Manuel de Carvalho não teve a repercussão esperada, pois só o Ceará aderiu com entusiasmo à sua idéia, guiado por Tristão de Alencar Araripe e pelo Coronel Filgueiras. Na Paraíba, no Rio Grande do Norte e nas Alagoas, poucas pessoas aderiram à nova República.

D. Pedro, irritado, tratou logo de debelar o movimento, começando por desmembrar de Pernambuco e anexar a Minas Gerais, a chamada Comarca do São Francisco. A esquadra comandada por Lord Cochrane, trazendo a bordo fôrças sob o comando do General Lima e Silva, partiu em agôsto, para o norte. Francisco Paes Barreto, em Barra Grande, esperava com suas forças o auxílio imperial. Desembarcando em Jaraguá (Maceió) Lima e Silva dirigiu-se a Barra Grande e juntando-se às fôrças de Paes Barreto, penetrou no território pernambucano, pelo sul.

As fôrças da Confederação eram poucas e fracas. Os senhores rurais em sua maioria, não apoiaram o novo govêrno e as tropas que Falcão de Lacerda reuniu foram colocadas na Ponte dos Carvalhos, próximo ao Cabo, a espera do inimigo. A pequena esquadra de três navios, comandados por Ratcliff, Metrovich e João Loureiro foi aprisionada por Cochrane e os seus chefes remetidos para o Rio onde foram enforcados. Lima e Silva, com $D$ apôio dos senhores de engenho, marchou até a altura das fôrças republicanas e aí teve com a mesma pequena luta, enquanto realizava um movimento de flanco que, passando pelo Engenho Sant' Ana, alcançou os Afogados, de onde passou-se para o bairro de 
Santo Antônio, ocupando-o. Dominavam os rebeldes o Recife e a Boa Vista, e se Falcão de Lacerda ocupasse os Afogados, colocaria Lima e Silva em cêrco, em situação de grande perigo. Mas, faltava aos rebeldes espírito de luta. O apôio popular começava a fugir-lhes à proporção que se distanciavam da vitória, e Manuel de Carvalho que se achava em Prazeres, para não cair em poder dos inimigos, recolheu-se ao navio inglês $T$ weed. Falcão de Lácerda marchou para Olinda, de onde passou-se para um navio estrangeiro, da mesma maneira procedendo Natividade Saldanha. Outros revolucionários tentaram escapar para o Ceará, pelo sertão, onde esperavam continuar a luta. Entre êles se achava Frei Caneca. Caminharam muitas léguas sempre perseguidos por fồças comandadas por Lamenha Lins, e ao se aproximarem do Ceará, foram atacados e se renderam no engenho do Juiz. No Ceará também a revolução fracassara e seus principais chefes haviam morrido, como Tristão de Alencar, ou haviam sido aprisionados.

Chegara agora a hora de $D$. Pedro que foi impiedoso com os vencidos, fazendo-os julgar por uma Comissão Militar que condenou à morte vários brasileiros. Assim foram executados no Rio de Janeiro, os três chefes da esquadra pernambucana. Em Pernambuco, além de Frei Caneca que foi fuzilado, foram executados - Major Henriques Agostinho Bezerra Cavalcanti, Nicolau Pereira, Antônio do Monte de Oliveira, Lázaro de Souza Fontes, James Rodgers e o Tenente Antônio Francisco Cardoso. No Ceará foram mortos o Padre Mororó, o Coronel de Milícias João de Andrade Pessoa Anta, o Coronel Fieliciano José da Silva Carapinina, o Tenente Luís Inácio de Azevedo Botão e Francisco Miguel Pereira Ibiapina. Escaparam da morte Manuel de Carvalho, Falcão de Lacerda, Natividade Saldanha, Coronel José Antônio Ferreira e o Capitão Carapeba, entre outros, por se acharem ausentes. $\mathrm{E}$ assim terminou o sonho republicano em Pernambuco. D. Pedro lavou-o em sangue.

\section{VI}

Passada a fase perigosa, a fase em que cabia ao Presidente pacificar os dois partidos opostos e reprimir enèrgicamente as desordens, apressou-se José Carlos Mayrink a declarar-se restabelecido e a tomar posse do govêrno para que fôra nomeado. Os revolucionários mais decididos estavam mortos, ou ausentes e sem poderem voltar à pátria, enquanto $D$. Pedro não recuasse em sua atitude perseguidora. O Margado do Cabo que despendera muito dinheiro na luta, via-se nas boas graças do Soberano. Iniciava-se 
uma fase em que os comerciantes portuguêses e os absolutistas, ao lado de homens que se interessavam apenas pelo poder, dominariam a província. Os homens de 1817 e de 1824 estavam afastados pela morte ou pelo exílio. Teríamos sete anos de domínio do absolutismo no qual a Presidência da Província seria exercicia por José Carlos Mayrink e, posteriormente, por Tomás Xavier Garcia de Almeida.

Só em 1826 se procederiam às primeiras eleições para o Senado e para a Assembléia Geral e, estando exilados, muitos pernambucanos ilustres a elas não concorreram. Foram eleitos deputados, neste ano, os políticos Pedro de Araújo Lima, futuro Marquês de Olinda, o magistrado Tomás Xavier Garcia de Almeida, Luís Francisco de Paula Cavalcanti de: Albiquerque, Antônio Francisco de Paula Cavalcanti de Albuquerque, Francisco de Paula de Almeida e Albuquerque, Domingos Malaquias de Aguiar Pires Ferreira, Manuel Caetano de Almeida e Albuquerque, Bernardo José de Serpa Brandão, Caetano Maria Lopes Gama, Padre Miguel José Reinau, Pedro Inácio Pinto de Almeida e Castro, Tomás Antônio Maciel Monteiro e Francisco José de Faria Barbosa. Em 1829, alguns dêles seriâm reeleitos, como Pedro de Araújo Lima, Antônio Francisco de Paula e Holanda Cavalcanti de Albuquerque, Luís Francisco de Paula Cavalcanti de Albuquerque, Francisco de Paula Almeida e Albuquerque, enquanto os demais foram. substituídos por Ernesto Ferreira França, Francisco de Carvalho Paes de Andrade, irmão do Presidente da Confederação do Equador, Gervásio. Pires Ferreira, Sebastião do Rêgo Barros, Padre Venâncio Henriques de Resende, Francisco do Rêgo Barros, Francisco Xavier Pereira de Brito e Manuel Zeferino dos Santos. Nesta nova eleição, quando já se tinha em Pernambuco uma atmosferd mais liberal, foram eleitos alguns deputados que participaram da revolução de 1824 e que possuiam até idéias republicanas, como Francisco de Carvalho e Venâncio Henriques de Resende (17).

Para o Senado, em 1826, em uma lista de 18 nomes, D. Pedro escolheria para Senadores os seguintes: José Carlos Mayrink da Silva Ferrão, que estando no govêrno da Província, fôra o mais votado, com 312 votos; o magistrado Antônio José Duarte de Araújo Gondim, segundo colocado; o Brigadeiro José Inácio Borges, nono colocado, e que era governador do Rio Grande do Norte, por ocasião da revolução de 1817, sendo prêso pelos patriotas; o médico José Joaquim de Carvalho, décimo colocado; Brigadeiro Ben. to Barroso Pereira, décimo-sexto colocado; e Antônio Luís Pereira

(17). - Afonso de E. Taunay, A Câmara dos Deputados sob o Império. "Anais do" Museu Paulista", n.० XIV, Ano de 1950. 
da Cunha, futuro Marquês de Inhambupe e que com apenas 148 votos colocara-se no décimo sétimo lugar na lista de votação (18). Nomes de grande mérito da província tiveram boa votação e foram cortados pelo "lápis fatídico" do Imperador, como Felipe Nery Ferreira e Gervásio Pires Ferreira. Teria ainda o Imperador guardado mágoas da Junta Governativa que José Bonifácio, para lhe servir, destituira?

Em junho de 1828, devido ao falecimento do Senador Antônio José Duarte de Araújo Gondim, foram procedidas novas elei- ções e Manuel Caetano de Almeida e Albuquerque foi escolhido em uma lista em que figurava ao lado de Luís Francisco de Paula Cavalcanti e Albuquerque e de Gervásio Pires Ferreira. Só ein 1837 , em pleno período regencial, se daria outra vaga de Senador em Pernambuco.

A repressão à revolução de 1824 tornou forte o partido absolutista em Pernambuco e quando D. Pedro malquistou-se com a opinião pública brasileira, pelas suas atividades anti-nacionais, formou-se nesta província, uma sociedade absolutista chamada Culuna do Trono e do Altar (surgida, segundo Pereira da Costa, em 1828 e segundo Alfredo de Carvalho, em 1829), da qual faziam parte o Vigário Francisco Ferreira Barreto e o Padre José Ma. rinho Falcão Padilha que, segundo Alfredo de Carvalho (19) "se impuseram a tarefa de propagar pela imprensa as suas doutrinas reacionárias". Esta sociedade que "trabalhava secretamente" e se reunia "em lugares diferentes" era na opinião de Borges da Fonseca, especialmente protegida pelo Presidente Tomás Xaxier Garcia de Almeida.

Ainda sôbre a mesma informa Pereira da Costa

"para fazer vingar a idéia que defendia, chegou a sociddade a conceber planos tenebrosos, e até mesmo a tentar contra a vida de algumas pessoas notáveis, que the eram adversas, ao mesmo tempo que procuravam chamar ao seu partido diversos oficiais militares, intento èste que foi frustrado, graças à enérgica atitude do General Francisco José Soares de Souza e Andréia, Comandante das Armas da Província" (20).

Não podemos deixar de referir sôbre esta sociedade, o trecho que se segue de Antônio Joaquim de Melo

\footnotetext{
(18). - Afonso de E. Taunay, $O$ senado do Império. São Paulo. Livraria Martins.

(19): - Alfredo de Carvalho, Anaris da Imprensa Periódica Pernambucana de 1821 a 1908, Recife. Tipografia do Jornal do Recife, 1908.

(20). - Pereira da Costa, Reminiscências histórico-pernambucanas, XXIX - "Sociedades Secretas", in "Diário de Pernambuco" de 18 de junho de 1902 .
} 
"Sob a presidência, em Pernambuco do Dr. Tomaz Xavier Garcia de Almeida, o Auditor da nefanda comissão militar de 1825, estabelecen-se na cidade do Recife a sociedade secrta - Columna do Throno e do Altar -- da qual já tratamos no tomo $2 .^{\circ}$. Por inspuração mormente dessa sociedade, da qual alguns sócios desaforados (em Parte Portuguezes) appellidavam trambolho a Constituição e jubilavam-se na illusoria perspectiva do Imperador sem trambolho, debatiam-se na imprensa e de viva voz o espirito e tendencia politica absolutista com a devoção e o aferro ao systema constitucional representativo. Que esteve a pique a acclamação do Governo abscluto no Brazil, vinda lá das alturas, é nossa humilde opinião, em sustentar a qual todavia não perderemos tempo, porque não a queremos impor a ninguem" (21.).

Eram jornais dessa sociedade O Cruzeito e O Amigo do Povo. Contra êles błatiam-se, como salienta Amaro Quintas, o Diário de Pernambuco, $O$ Constitucional, $A$ Abelha Pernambucana e $A$ Bússola da Liberdade. Sôbre a atuação do Diário de Pernambuco, nas lutas políticas de então, afirma Alfredo de Carvalho,
"Assim conservou-se mero noticiário comercial - 6 Diário de Pernambuco - até 1828, quando aumentou de formato e começou a tomar feição política em meio das contendas partidárias da época, batendo-se ardente- nente em prol dos princípios liberais, ao lado de $\dot{A}$ Abelha Pernambuaana e do $O$ Constitucional contra os or- gãos absolutistas $O$ Cruzeiro e $O$ Amigo do Povo, atitude esta que acarretou ao seu proprietário uma agressão pes- soal, por parte do Tenente-Coronel Francisco José Mar- tins, que o deixou bastante maltratado.
Nos três anos imediatos (1829-1831), o jornal foi um dos mais resistentes baluartes do constitucionalismo, gra- ças à assidua colaboração dos Padres Lopes Gama e Ve- nâncio Henriques de Resende, e do Cirurgião .Jerônimo Vilela Tavares; depois de 7 de Abril constituiu-se pro- vugnador dos principios federalistas que lograram certo predomínio na opinião pública durante os primórdios da Regência" (22).

Do nome da sociedade absolutista, derivou o apelido dado aos partidários do primeiro Imperador de "colunas" e esta sociedade era tão prejudicial que quando o Marquês de Barbacena entrou nas boas graças do Imperador e teve sôbre o mesmo certa influência, mandou fechá-la (23),

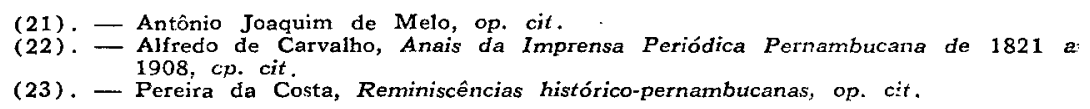




\begin{abstract}
"Por aviso de 12 de dezembro de 1829 , expedido peIo Ministro Visconde de Alcântara ao Presidente do Trabunal de Relação do Recife, em virtude de uma representação do mesmo Comandante das Armas contra a Coluna, foi mandado proceder a um sumário crime, e verificando-se então ser a sociedade um conventículo sedicioso na forma do art. 6 da Carta de Jei de 20 de outubro de 1823 , procedesse a devassa de que trata a mesma Iri, e prosseguisse contra os criminosos".
\end{abstract}

Claro que contando com gente de elevada posição social, co: mo militares graduados, padres, magistrados e comerciantes, a sociedade não se extinguiu e, sob as vistas complacentes das autoridades provinciais, continuou a sua campanha anti-liberal.

Contra a Coluna trabalharam os liberais em outra socieáade, a Jardineira ou dos Carpinteiros de São José, fundada no Rio de Janeiro e cuja secção pernambucana começou a funcionar en 1829, contando em seu seio com Antônio Borges da Fonseca, Ernesto Ferreira França, Dr. Matias Carneiro Leão, Antônio Carneiro Machado Rios, que seria um dos maiores agitadores do período regencial, Sebastião do Rêgo Barros, o comerciante Mazza, Dr. Francisco Xavier Pereira de Brito e o major de engenheiros José Joaquim Vieira Souto. Êstes pugnavam pelo respeito à Constituição e pela manutenção do regime constitucional.

Ainda em 1829, houve uma pequena sedição da qual participaram os irmãos Roma, que tendo fracassado em igual tentativa em junho de 1827, tentaram uma segunda, nos Afogados, parece que com sentido republicano e, derrotados se retiraram para Santo Antão e daí para Cimbres, onde se dispersaram ( $O$ Cruzeiro de 5 e 21 de maio de 1829).

O Deputado Holanda Cavalcanti, que na Câmara combateu a nomeação de Tomás Xavier para Presidente da Província de Pernambuco, por haver o mesmo perseguido aos pernambucanos após a derrota dos confederados de 1824, chegou a dizer sôbre esta revolta que

"elles impellidos pelo desejo natural de liberdade, e desconfiados que a nomeação de tal presidente e o desprezo da Constituição os levava aos antigos ferros do despotismo, a isso se arrojarão".

Esta era a situação da Província de Pernambuco ao iniciarse o ano de 1831, onde autoridades de tendências nitidamente ab. solutistas, assistiam à luta que se travava na imprensa e nas conversas e opiniões de rua, entre os absolutistas e partidários incondicionais do Imperador, apoiados em grande parte no numeroso 
corpo de comerciantes portuguêses do Recife e os monarquistas liberais e republicanos que queriam e defendiam a liberdade, esperando que os heróis de 1824 voltassem à pátria e pudessem disputar aos senhores do dia, os cargos de importância por êles ocupados.

Dia a dia os liberais ganhavam terreno. Para se tirar tal conclusão, basta que se compare os deputados eleitos em 1826 com os eleitos em 1829. Basta que se leia os jornais da época. Diante desta situação chegaria em maio de 1831, inesperadamente, a notícia da abdicação de D. Pedro I e com ela a agitação política pernambucana atingiria o climax. Teríamos talvez o ano mais agitado da nossa história.

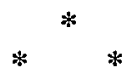

\section{PERNAMBUCO E A ABDICAÇÃO.}

Só a 5 de maio chegaram a Pernambuco as notícias, confirmadas no dia seguinte pelo brigue Imperial Pedro, de que D. Pedro I, premido por grandes manifestações populares, com as quais as tropas haviam compactuado, resolvera abdicar em favor de seu filho D. Pedro de Alcântara, D. Pedro II que reinaria no Brasil de 1831 até 1889 .

A imprensa deu grande divulgação; o Diário de Pernambuco - que já era, então, um dos jornais mais importantes ja província - dedicou-lhe tôda a primeira página; a notícia veio encontrar a opinião pública da província inteiramente dividida. De um lado, estavam os revolucionários de 1817 e 1824, alguns ainda republicanos, outros mais moderados, monarquistas constitucionais que, embora vencidos e perseguidos, contavam com grande número de adeptos. Muitos eram olhados com respeito e simpatia pela maioria da província, devido aos feitos que os recomendavam. Do outro lado, estavam os portuguêses que desfrutavam bons cargos no govêrno de $D$. Pedro I. Havia os que tiveram receio de fazer oposição a um govêrno francamente absolutista como o do primeiro Imperador $e$, ainda, os oportunistas.

Aos primeiros estavam ligados geralmente os habitantes do Recife, as pessoas de poucos recursos, geralmente menos temerosas das reformas políticas e os que não haviam conseguido posições e empregos no govêrno do primeiro Imperador. Aos segundos acompanhavam os que se dedicavam às atividades comerciais, quase todos portuguêses, e que também tinham grande infiltração nos cargos públicos e militares, graças à atenção que thes dis- 
pensavam as autoridades absolutistas, dentre as quais se desta-cavam por sua intransigência, o Coronel Lamenha Lins e o Desembargador Gustavo Adolfo de Aguilar Pantoja.

Apesar desta situação, a notícia da abdicação foi muito festejada no Recife, conforme afirma uma testemunha, Antônio Joc.-. quim de Melo, em sua biografia de Gervásio Pires Ferreira

"foram muitos os aplausos e regozijos públicos; toda. a cidade illuminou-se à noite e a percorreram grandes bandos de pessôas com escolhidas e alegres músicas; os fogos do ar e os vivas foram incessantes, intermediados às vezes por improvisos poeticos. Tão imprevisto successo. verificou-se na existência en Pernambuco de rivalidadcs e azedumes politicos que a estonteada Columna do Throno exacerbara e nutrira, por onde receiavam-se excessos turbulentos e vinganças culposas daquelles que julgavam-se victoriusos contra os contrários envergonhados e temerosos, alguns dos quaes desapareciam e occultavam-se, mas ninguem foi offendido, nem levemente desa-. catado".

Mas o poder dos absolutistas era grande, boas posições eram por êles ocupadas; assim, o Coronel Lamenha Lins que em 1824 tomara parte saliente na luta contra os republicanos da Confederação do Equador e que se destacara na Guerra Cisplatina, ocupando agora o Comando das Armas da Província, procurava a conseguia salvaguardar os interêsses do seu partido, protegendo os absolutistas e tolhendo a ação dos liberais, quando nomeava os primeiros para posições chaves e preteria os segundos. Procurava intpedir que os oficiais implicados na revolução de 1824 voltassem às fileiras e, destacava os simpáticos ao liberalismo para a ilha de Fernando de Noronha, onde êles ficavam pràticamente afastados dos seus e de uma ação política mais intensa (24).

A situação da província continuou difícil, mesmo após o notim de 6 \& 7 de maio, pois o prestígio e influência dos absolutistas que desde 1825 desfrutavam o poder, era grande e espalhado por tôda a parte. Na capital, a influência portuguêsa era considerável e grande era o número de "adotivos" no exército, alguns dêles bem ligados ao Brasil, como os Coronéis Aleixo José de Oliveira e José Joaquim Coelho, enquanto outros excessivamente turbulentos. No interior, muitos chefes locais propagavam e impunham as idéias absolutistas, como o Padre Jacinto de Maringabas, na vila de Santo Antão, onde, com o Juiz de $\mathrm{Paz}$ e o escrivão - um portuguès que se achava no Brasil em 1822 e "não jurou a constituição" -

(.24). - Diário de Pernambuco, n..$^{\circ}$ de 10 de setembro de 1831. 
pregava que o Imperador voltaria ao govêrno e os liberais e seus filhos seriam passados pelas armas (25).

Nos confins da província, em Flôtes, a Câmara da Vila a 4 de julho informava ao Govêrno temer um ataque do ex-Capitãomor José da Costa Nunes que diziam ser aliado de Pinto Madeira, chefe absolutista do Carirí, no sul do Ceará (26). No têrmo de Una, sul de Pernambuco, via-se o Juiz de $\mathrm{Paz} \in \mathrm{m}$ situação difícil para debelar as desordens provocadas pelo Tenente-Coronel de Mi1́cias João Batista, de Barra Grande que seria um dos chefes cabanos, cuja influência se estenderia até a vila de Abreu, nesta província, onde provocaria sérias desordens (27), nas quais até perdeu a vida um seu irmão (28). Contâvam os absolutistas com tanta fôrça que mesmo após o 7 de abril, se reuniam constantemente $\mathrm{em}$ casa de um Sr. Coló, no Monteiro, como denunciou a Sentinela Pernambucana (29).

Nesta situação, ao ter conhecimento da boa nova e sabendo da situação de fraqueza do Govêrno, parte da tropa da Capital, tendo à frente o Capitão Francisco Inácio Ribeiro Roma, resolveu fazer, ao mesmo, algumas imposições. Estas eram as mais justas, pois não se compreendia que se permitisse continuar a gerir grande parte dos negócios da província, homens até então comprometidos com o govêrno que acabara de cair. Para conhecer melhor a fôrça de que dispunha, o Capitão retirou-se com os seus homens (40 a 50) do Batalhão 18 de 1a. linha, levando armas e cartuchame para a cidade de Olinda. O Presidente da Província, José Joaquim Pinheiro de Vasconcelos, que reunira o Conselho de Govêrno, no mesmo dia 6 , para comunicar as notícias recebidas e tomar as providências que se fizessem necessárias, contou com o comparecimento dos conselheiros Francisco de Paula Cavalcanti de Albuquerque, Deão Bernardo Luís Ferreira, Gervásio Pires Ferreira, Manuel Zeferino dos Santos, Desembargador Tomás Antônio Maciel Monteiro e Dr. Manuel Inácio de Carvalho. Reunido o Conselho, conforme reza a ata do dia

"O Sr. Presidente disse que havia convocado o Conselho para the communicar que, por officios do Ministro e Secretario d'Estado dos Negócios do Império, chegados nrsta mesma manhã, pelo Paquete Imperial Pedro, se via ser certa a noticia de gloriosa revolução, acontecida na Cidade do Rio de Janeiro, pela qual fúra elevado as throno o Sr. D. Pedro 2: - acontecimento que deveria fazer

\footnotetext{
(25). - Idem n. ${ }^{\circ}$ de 16 de agôsto de 1831

(26). - Idem, n. ${ }^{\circ}$ de 12 de julho de 1831 .

(27). - Idem, n. ${ }^{\circ}$ de 12 de julho de 1831 .

(28). - Carta de Antônio Borges da Fonseca, in Diário de Pernambuco, n. ${ }^{\circ}$ de 30 de agôsto de 1831 .

(29). - Diário de Pernambuco, n. ${ }^{\circ}$ de 18 de julho de 1831.
} 
transbordar a alegria dos verdadeiros amantes da Constituição e da elevação do Brasil: pelo que the parecia justo que todos os habitantes desta Cidade dessem demonslrações do seu contentamento, e por isso acertaro par. tecipar à Camara Municipal tão fausta notícia, afim de que ella a transmitisse ao povo e receiando que nos excessos deste tão justo applauso se não perturbasse de al. guma forma a tranquilidade publica pela suspeição em que estavão alguns Empregados Públicos desta Província, principalmente militares, the parecia tão bem acertado proclamar ao Povo nesse sentido; proposicões estas que foram unanimimente aprovadas pelo Conselho, e que immediatamente se pozeram em effeito, passando logo depois disto o mesmo Exmo. Sr. Presidente e Conselheiros a presentarem-se na Galeria do Palácio, em cuja Praça já se achavam as bandas de música de todos os Corjos Militares e muito Povo, ahi deu S. Exc. o Sr. Presidente vivas à Briosa Nação Brazileira, à Constituição do Império, ao Imperador o Sr. D. Pedro 2. ${ }^{\circ}$ e à Assembléia Geral Legislativa, vivas a que o Povo correspondeu com muito enthusiasmo; e, findos estes, ordenou as bandas de música que fossem girar pelas ruas da cidade: com 0 que se dispersou o Povo" (30).

Logo após, era comunicado ao mesmo Conselho, pelo Coman. dante do Batalhão 18, a retirada da tropa do Capitão Francisco Roma e o Presidente resolveu, com o apôio do Conselho, enviar ao referido Capitão, como mediadores, o conselheiro Francisco de Paula e o seu Secretário, aceitando os mesmos a incumbência. Entrementes, soldados de outras unidades e paisanos armados, partiain ao encôntro da fôrça, para apoiá-la, e os enviados do Govêrno näo conseguiram fazer com que a tropa voltasse ao quartel, justamente porque a isto se opuseram os paisanos que a acompanhavam. Em pouco tempo o ajuntamento formado $\mathrm{em}$ Olinda ganhou importância porque a êle aderiram vários oficiais como, entre outros, os Majores Francisco Antônio Pereira dos Santos e Pedro Antôrio Veloso da Silveira, lentes do Curso Jurídico, como Manuel José da Silva Pôrto e João José de Moura Magalhães, heróis da Ccnfederação do Equador como Jasé Maria Ildelfonso, estudantes, tropa e povo.

Depois dos entendimentos havidos entre Francisco de Paula e os amotinados, resolveram êstes enviar ao Presidente a interessante representação que se segue e que será transcrita por extenso devido à importância que tem.

"Illm. e Exm. Sr. O povo de Recife, e Olinda, Estudantes do Curso Juridico, tropa de sua guarnição e Cor-

(30). - Antônio Joaquim de Melo, Apensos à biografia de Gervásio Pires Ferreira. Recife, 1895. 
pos militares de uma e de outra Praça, actualmente reunidos em Olinda, cheios de suspeitas de que alguns Commandantes militares e outros subalternos, além de algurnas autoridades desta Provincia bem conhecidas por sua conducta anti-nacional e opiniöes abertamente absolutistas, não se queiram oppôr a execução legal das Ordens da Regência, ora installada no Rio de Janeiro, e por em pratica tentativas perniciosas a nossa liberdade, tendo de mais justos receios de que o estado de irritação e azedume em que se acham actualmente os espiritos haja de produzir algum funesto resultado entre a multidão, e convencidos de que o unico meio de aplacar-se a conflagração geral, que parece querer abrasar-nos, é a immediata e prompta demissão dos empregados mal vistos do Povo, inploram a V. Exc. para que, ouvindo o Conselho do Govêrno segundo a lei de 20 de Outubro de 1823 , proceda a demmissão peremptoria dos empregados abaixo nomeados substituindo-os por Brazileiros natos, dignos da confiança pública; ficando os supplicantes bem certificados de que V. Exc. e o patriotico Conselho, que o rodeia conhecendo os votos do Povo, não deixarão de por em execução estas unicas medidas, que sós podem restaurar a paz e a tranquillidade alteradas. Os empregados de que fallamos são os seguintes: o Coronel Bento José Lamenha I.ins, o Dezembargador Gustavo Adolfo de Aguilar, o Dezembargador Antonio de Azevedo Mello e Carvalho, o Chanceller Francisco José de Freitas, o Tenente-Coronel Francisco José Martins, o Tenente-Coronel Antonio Cardoso Pereira de Mello, o Major Manoel José de Castro, o Major Graduado Francisco Felix de Macedo, o TenenteCoronel Joaquim de Souza Meirelles, o Major Manoel Muniz Tavares, o Major Pedro Borges de Farias, o CapitãoMór Domingos Lourenço Torres Gallino, o Capitão Antonio Gomes Leal, o Major Trajano Cesar Burlamaque. Olinda, 6 de maio de 1831".

Seguem-se algumas dezenas de assinaturas, emcabeçadas pelo Capitão Francisco Roma (31).

A representação apesar de feita em têrmos respeitosos, uma vez que os reunidos "imploram" ao Presidente e ao Conselho, em. "lugar de exigir, ou mesmo sugerir, era ao mesmo tempo enérgica, pois era firmada sob a alegação de ser feita em nome dos estudantes, do povo e da tropa das duas mais importantes cidades da província, apontando nominalmente as pessoas consideradas suspeitas e apresentando o castigo que deveria ser imposto às mesmas. Convém salientar os postos importantes que eram pelos mesmos ocupados, pois na lista figurava o próprio Comandante das Armas, chefe supremo das fôrças sediadas na província e que participava da reunião do Conselho, dois Desembargadores, os co-

(31). - Antônio Joaquim de Melo, op. cit. 
mandantes dos Batalhões 18 e 19, de primeira linha e uma série de vários oficiais superiores, além do irrequieto Capitão-mor de Santo Antão.

Ao tomar conhecimento do desêjo dos sublevados, resolveram o Presidente da Província e o Conselho, que se mantinha em sessão permanente, enviar no dia seguinte, a fim de terem novos entendimentos com os amotinados, os Conselheiros Gervásio Pires Ferreira e Manuel Zeferino dos Santos, os quais deviam entrar em entendimentos com o Presidente da Câmara do Recife, Antônio Joaquim de Melo, para agirem de comum acôrdo. Este já se achava em Olinda tentando persuadir a tropa a voltar aos quartéis, sem conseguir os seus intentos, pois durante a noite

"desertou tôda a tropa de linha, a mor parte da poIiría abandonando tôdas as guardas, até mesmo a guarda do Palácio, e, constando que além da Tropa de Linha tiuham sahido já alguns milicianos e mais pessôas do povo"

resolveu o Conselho aceder às exigências formuladas, substituindo as autoridades suspeitas aos pernambucanos. As 5 horas e meia da manhã do dia 7 , os dois conselheiros designados no dia anterior, acompanhados do novo Comandante Interino das Armas; - Coronel Francisco Jacinto Pereira, partiram para Olinda e participaram, aos reunidos, que as exigências haviam sido aceitas e comunicando aos mesmos as substituições que foram feitas. Todos então se conformaram e

"pelas dez do dia entrou toda a tropa e muita parte do povo em perfeita ordem e marcha militar, commandados pelo dito Commandante das Armas e alguns dos novos Commandantes dos Corpos, e, dirigindo-se à Praça de Palácio, desfilaram perante o Exmo. Sr. Presidente, correspondendo aos vivas patrioticos por elle dados con o maior enthusiasmo, sem que durante todos estes acontecimentos houvesse, quer nesta cidade, quer no caminho por onde os differentes grupos de tropas marcharam para a cidade de Olinda, quer finalmente na mesma cidade e no regresso da tropa e povo. um só ataque à propriedade, um só insulto pessoal".

Às 11 horas do dia 7, deu-se por finda a sessão, sendo recigida a ata pelo Secretário do Govêrno e do Conselho, Vicente Tomás Pires de Figueiredo Camargo (32).

Mas a paz não dominaria a província, pois além dos absclutistas, transformados após a abdicação, em restauradores, e orga-

(32). Ibidem. 
nizados em poderoso partido político, havia, ainda, como consequuência das lutas políticas e da instabilidade social e econômica, grupos de salteadores que agiam em todos os lugares, notadamente no têrmo da vila de Escada (33), nas proximidades da. Capital onde dominavam desde o lugar Pau Sêco até a Ponte dos Carvalhos. A sociedade era formada em sua imensa maioria de senhores e escravos, permanecendo quase todo o movimento comercial na mão de portuguêses, havendo dificuldade de emprêgo para os homens livres que não possuíam recursos.

A desmoralização era geral atingindo também a classe clos funcionários e dos militares, pois havia uma tão desenfreada apro- priação indébita de bens e dinheiros públicos, que mais tarde um novo Comandante das Armas, enviado da Côrte, o Brigadeiro Francisco de Paula e Vasconcelos, teve de agir enèrgicamente contra oficiais de alta graduação (34).

Outra grande praga era a fabricação de moedas falsas, de cobre, em larga escala, impossibilitando as pessoas de fazerem transações à base de tal moeda, com receio de prejuízos. Isto agitava sobretudo a camada mais pobre da população, que não cispunła - de outras moedas de maior valor. Tão grande era o número destas fábricas, que o Govêrno se viu obrigado, certa vez, a proithir a venda de fôlhas de cobre (35), demonstrando não poder reprimir eficazmente os falsários. O Comandante Interino de Polícia, Luís de Moura Accioly, chegou a apreender duas fábricas de dinheiro falso, dando uma ronda, no início de setembro de 1831, na itha do Nogueira, próxima ao aterro dos Afogados, necessitando de carroças, para transportar o material apreendido (36). Só nesta ilha, no perímetro então suburbano da cidade, se achavam duas fábricas descobertas em um só dia, daí poder calcular-se a quantidade delas em tôda a província.

Por estas razões, vitoriosa a sedição de 6 de maio, compreenderam os homens ricos da província, possuidores de fortunas, que necessitavam se congregar em defesa da ordem e dos seus interêsses. Compreendendo que a ordem seria mantida mais fàcilmente se fizessem diminuir os ódios então dominantes entre os exaltados - federalistas e republicanos - e os mais reacionários "ccivinas" -, procuraram sob a inspiração de Antônio Joaquim de Melo, fundar a Sociedade Patriótica Harmonizadora que, como đizizia êste mesmo cidadão,

\footnotetext{
(33). - Diário de Pernambuco, de 4 de agôsto de 1831

(34). - Idern, de 16 de agôsto de 1831 .

(35). - Idem, de 28 de julho de 1831 .

(36). - Idem, de 7 de setembro de 1831 .
} 


\begin{abstract}
"reunindo-se os homens e discutindo, convergissem a um comportamento liberal e vigilante sim, mas hones to e justo, moderado e honroso"
\end{abstract}

e continuava

“Acceitar a abdicação, promover que não se proseguisse as suspensões, deposições e perseguições de empregados e outras pessoas por suas opinióes politicas antericres, soccorrer os orphãos desvalidos, cujos pais foram. imolados judicialmente pelas commoçóes politicas e oppôr-se a restauração, tudo por meios honestos e não contrarios à lei" (37).

Segundo o próprio Antônio Joaquim de Melo ela era "o partido moderado e que tinha como órgão de imprensa o jornal o Harmonizador". Desta Sociedade participavam figuras importantes na província, como Francisco Antônio de Oliveira, futuro Barão de Beberibe, Laurentino Antônio Moreira de Carvalho, Dr. Simplício Antônio Mavignier, Gervásio Pires Ferreira, Dr. Antônio Peregrino Maciel Monteiro, os professôres de direito, Marcos Antônio de Araújo Abreu, Pedro Francisco de Paula Cavalcanti de Albuquerque, e negociante Francisco Antônio de Oliveira, José Alexandre Ferreira, o Vigário Virgínio Rodrigues Campelo, os proprietários Tomás da Silva Gusmão e Bento José da Costa Júnior, o Capitão-Tenente da Marinha Antônio Pedro de Carvalho, que ofereceria séria resistência à Setembrizada, alguns meses depois, José Francisco de Melo Cavalcanti e João Francisco Cavalcanti de Albuquerque, senhores de engenho, além de inúmeros proprietários, comerciantes e militares. Da leitura da relação dos sócios da Patriótica Harmonizadora, se nota que quase todos, pela posição que ocupavam, eram homens de haveres, homens que possuindo fortuna, temiam que as agitações políticas e "rusgas" subseqüentes trouxessem prejuízos. Procuravam manter a otdem na província, porque, assim fazendo, resguardavam suas posições e haveres e demonstravam compreender que a moderação, que era o meio caminho entre a restauração e domínio dos portuguéses e a federação que poderia levar à república e conseqüente à abolição do tráfico de escravos, ou mesmo do cativeiro, era para êles o caminho mais seguro.

Tal era a situação da província quando aportou em Recife, em junho de 1831, o Brigadeiro Francisco de Paula e Vasconcelos, a fim de exercer o Comando das Armas e recebeu tal cargo do Comandante interino que o exercera desde 7 de maio, no dia

(37). - Antônio Joaquim de Melo, op. cit. 
30 do mês citado (38). O novo Comandante das Armas inspirava confiança aos pernambucanos, pois fôra figura saliente nos acontecimentos do 7 de abril e também o primeiro oficial superior que partiu com os seus comandados ao encôntro do povo que exigia do Imperador a demissão do Ministério que não merecia confiança dos brasileiros. Era um homem que se recomendava por suas idéias federalistas. Um seu irmão, Miguel de Frias, que também tomou parte saliente nos acontecimentos que provosaram a abdicação, se destacaria, logo após, no Rio de Janeiro, por suas idéias exaltadas, fortemente liberais. Confiantes na ação do Brigadeiro e na vitória da causa liberal, os elementos anti-absolutistas começaram a se reunir em tôrno da bandeira da federação e passaram a exigir a dispensa dos cargos públicos e até a expulsão dos portuguêses e dos "colunas", partidários dêstes. A 14 de julho de 1831, o Diário de Pernambuco comentava até que circulavam boatos na cidade de que tais reivindicações seriam apresentadas ao Govêrno, à mão armada, e condenava os meios que se cogitava empregar.

A idéia federalista continuava a conquistar sempre maior número de adpetos, tanto que êste mesmo jornal, a 20 de agôsto, dizia que a mesma, que quase desaparecia em 1824 -, ano $€ \mathrm{~m}$ que esteve no auge -, agora florescia e ia ao extremo, para a época, de afirmar

"Decerto a feilicidade de nenhum povo depende de reis; antes pelo contrário êles são sempre á causa da ruína e atrazo das nações"

e continuava

“A Federação quer seja autorizada pela Assembléia quer se realise por vontade geral da própria nação é igualmente legal, e justa, é igualmente o voto de todos os brasileiros".

Esta era a opinião manifestada na cidade que olhava o campo, onde não havia povo, mas apenas senhores de engenho, proprietários e escravos, com desconfiança, a ponto de, meses depois, a Bússola da Liberdade fazer uma resenha histórica para demonstrar

"que as familias aristocráticas da Bahia, e Pernambuco, com raras excepções individuais, tem sempre sido os baixos, e servis autores das desgraças, e escravidão do povo brasileiro" (39).

(38). - Diário de Pernambuco de 4 de julho de 1831

(39). - A Nova Luz Brasileria, n. ${ }^{\circ}$ de 15 de setembro de 1831. 
Tal oposição aos senhores de engenho, aos grandes proprietários de terras, era uma consequiência da atitude dêstes que, animados com a valorização do preço do açúcar, se preocupavam mais com os seus problemas econômicos, com os problemas ligados à lavoura, como o tráfico dos escravos, que com as discussões de caráter político em que se empenhavam os habitantes das cidades. Além disto, dispondo os senhores de engenho de ilimitado poder em suas propriedades, recebiam geralmente de bơm grado o absolutismo do monarca que, geralmente, tornava-se muito atenuado na porteira dos grandes engenhos. Não devemos mesmo esquecer que foi pequena a repercussão da Confederação do Equador no campo, onde, o Morgado do Cabo que fôra revolucionário em 1817, em 1824 se opunha aos seus ideais de 7 anos atrás, contando com substancial apôio, inclusive da familia Cavalcanti de Albuquerque, descendente do Coronel Suassuna.

Mas o Brigadeiro Francisco de Paula e Vasconcelos, apesar de federalista, procurou agir com a máxima moderação, procurrı reparar as injustiças feitas pelo Coronel Lamenha Lins e punir cs oficiais que não se portavam honestamente nas funções, assim como dar à província a paz necessária ao seu desenvolvimento. Criou um clima de ordem e respeito, tomando uma série de niedidas enérgicas e necessárias.

Logo a 12 de julho, visando esquecer as lutas do primeiro Reinado e reparar injustiças dos seus antecessores, convidou os oficiais da tropa de 1a. linha, que se achavam desempregados, a voltarem às fileiras, pois havia nas mesmas falta de oficiais, a fim de que pudessem receber os soldos a que tinham direito (40), convindando-os a se apresentarem no dia 28, às 9 horas da rranhã, na Secretaria do Comando das Armas (41). Consultado o Presidente sôbre o sôldo a ser pago a êsses oficiais, respondeu que êles tinham direito ao sôldo pago na época (42), como os que jä se achavam no serviço ativo. Ainda para minorar a situação difícil em que êles se achavam, o Comandante das Armas propôs ao Presidente que adiantasse a cada um a importância de cem mil réis para se fardarem, pois tal importância poderia ser descontada mensalmente dos seus ordenados. Tal atitude vinha melhorar a situação em que se achavam os oficiais desempregadus há 7 anos e que vinham sendo perseguidos em todo êste períodis.

Esta atitude teve dupla repercussão: assim, enquanto alguns absolutistas se indignavam com a mesma, outros protestavam sua fidelidade à Regência e se proclamavam seus partidários, embora, 
antes de 7 de abril, fôssem governistas ferrenhos. Muitos dêles, como o Major José Joaquim Luís de Souza, por exemplo, que foi afastado de suas funções na Paraíba por ser absolutista, prestaria depois inestimáveis serviços, com grande dedicação à Regência, na repressão aos Cabanos, restauradores que durante tiês anos ensanguentaram o sul de Pernambuco e o norte das Alagoas. Houve assim adesões sinceras ao lado das oportunistas.

Nãó foi apenas esta a medida do Comandante das Armas. no que diz respeito à tropa; assim, procurou afastar da mesma os elementos suspeitos à causa nacional, ao mesmo tempo que outros eram afastados dos postos chaves. Mandou suspender o pagamento do abôno ao Alferes do Corpo de Polícia, Antônio Pinto, cue era português, até que êle provasse se achar no Brasil em 1822 - ano da independência - e de não haver lutado contra a mesma no exército lusitano. Estas medidas tomadas no sentido de afastar os portuguêses e fazer voltar ao exército os implicados na revolução de 1824, trouxeram grande confusão pois pessoas cue nunca haviam sido "colunas" - alcunha dada pelo vulgo aos partidários da restauração - foram acusadas de o ser, como o moderado Capitão Padilha, acusado pelo Capitão Roma, de possuir tal idéia, tendo sido defendido pelo próprio Diário de Pernambuco em seu número de 12 de agôsto de 1831. Ao contrário, os Srs. Francisco Joaquim Pereira de Carvalho e João Rodrigues da Silva intitulavam-se revolucionários de 1824, para auferir vantagens, quando, neste ano, bateram-se contra a mesma revolução (43).

Pela redução das despesas com a tropa e moralização do comando, também se bateu o ilustre Comandante das Armas, no curto período em que exerceu tal pôsto; assim, como por decreto de 4 de maio de 1831, o 19. Batalhão deixou de ser destacado, para fazer parte da guarnição da capital, fêz êle suspender o pagamento de aluguéis de casa a que tinham-direito os oficiais do mesmo, assim como os abonos das etapas que recebiam como destacados (44). Informado de que havia oficiais comandantes, Majores e Ajudantes, que não estando em exercício, recebiam as gratificações do cargo, pediu informações aos mesmos para impedir tal irregularidade (45). Ainda, moralizando a tropa e economizando o dinheiro da fazenda nacional, ao encontrar um deficit de $1.439 \$ 095$ no $4 .^{\circ}$ Corpo de Artilharia de Posição, ordenou aos responsáveis, Srs. Antônio Cardoso Pereira de Melo e Major Manuel José de Castro, que repusessem a quantia (46), como o fêz

(43). - Correspondência, "Diário de Pernambuco", de 31 de agôsto de 1831 .

(44). - Diário de Pernambuco, de 23 de julho de 1831.

(45). - Idem, de 23 de julho de 1831 .

(46). - Idem, de $1 .^{\circ}$ de agôsto de 1831. 
também ao Comandante do $13 .^{\circ}$ Batalhão de 1a. Linha, determinando

"que faça entrar sem perda de tempo, por todos os meios que estiverem ao seu alcance, para a caixa da Adininistração, a quantia de $420 \$ 080$ que falta na mesma" (47) .

Ainda determinou o afastamento de baterias de São Francisco, Montenegro e Pau Amarelo, por serem as mesmas desnecessárias e não interessar à Fazenda Nacional pagar gratificações aos respectivos comandantes (48). Tantas foram as medidas moralizadoras tomadas pelo Brigadeiro Paula, que até parecia que a Província vinha sem Comandante das Armas, há vários anos, o que era uma forte acusação ao Comandante Lamenha Lins, em cuja administração se deram tão grandes e perniciosas faltas.

Mas a diligência e atuação do Brigadeiro Paula não ficou nestas medidas, pois lembrou-se também dos seus soldados e dos presos, reclamando por melhor alimentação para os primeiros e por uma justiça mais rápida para os segundos. Dizia êle em ofício ao Presidente (49) que a justiça era tão morosa que as cadeias estavam cheias, devendo o Conselho de Guerra julgar os casos com mais rapidez

"afim de ver se he possivel aliviar a sorte daqueles desgraçados",

o que constituia, inegàvelmente, um grande mal, e a alimentação fornecida à tropa, era tal, que

"os gêneros de que se compõe o rancho dos soldadus é de farinha negra, e ammargosa, e toucinho péssimo, e tudo mais a proporção"

e, por isto, ordenou êle ao Comandante do $4 .^{\circ}$ Corpo de Artilharia de Posição, onde constatara o péssimo estado do rancho que

"quando houvesse de receber tais gêneros, sempre que fôssem de má qualidade não aceitasse, e me requisitasse"

e quando tal fato se deu, êle se dirigiu ao Presidente Pinheiro - 30 de julho de 1831 - pedindo providências (50).

(47). - Idem, de 31 de agôsto de 1831 .

(48). - Idem, de 8 de agôsto de 1831 .

(49). - Idem, de 17 de agôsto de 1831 .

(50). - Idem, de 8 de agôsto de 1831 . 
Além dessas medidas tomadas pelo Comando das Armas nos meses de julho e agôsto, salientam-se as atitudes tomadas pelo Govêrno para combater o banditismo que se alastrava até o bairro de Pombal (51) e a cunhagem da moeda falsa, que muito difundida, prejudicava principalmente o pequeno comércio, agitando a população menos favorecida.

No combate ao primeiro mal, ordenou o Presidente às Câmaras de Serinhaém (52) e de Escada (53), que organizassem rondas e batessem, com os recursos de que dispunham, os salteadores. Ao mesmo tempo confiava ao Sargento-mor, Francisco Antônio Pereira dos Santos, nomeado pelo Conselho da Província, Comandante das Guardas Municipais, o combate aos que operavam pelo Pau Sêco e pela Ponte dos Carvalhos, na vizinhança da capital. Este militar tinha como campo de ação Recife, Olinda, Beberibe, Jaboatão, Poço da Panela, Várzea e Afogados, percebendo o ordenado mensal de $50 \$ 000$, que dependia de homologação da Regência (sessão de 23 de agôsto de 1831, publicado no Diário de Pernambuco de 9 de setembro do mesmo ano), e era coadjuvado por Antônio Carneiro Machado Rios (53a). Em pouco tempo essas imediações se viram livres dos salteadores, graças à energia com que agiu a fôrça que os perseguia.

Para o combate à moeda falsa, foram organizadas rondas que destruiram as fábricas e apreenderam o material encontrado nas mesmas, procedendo-se à punição dos criminosos que foram localizados. Mas a luta contra os moedeiros falsos foi muito séria, pois vários anos depois êste flagelo ainda não havia sido debelado.

Tal era a situação da Província quando, no decorrer do mês de setembro, o govêrno e o povo foram surpreendidos pela Setembrizada.

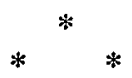

\section{A SETEMBRIZADA.}

Além das várias providências tomadas pelo Comandante das Armas, para solucionar os casos que the foram apresentados, temos de acrescentar o fato de não poder o mesmo confiar na tropa. A inquietação das ruas tinha ressonância nos quartéis, onde oficiais, políticos muitas vêzes, não impunham disciplina aos seus su-

(51). - Idem, de 8 de agôsto de 1831 .

(52). - Idem, de 4 de agôsto de 1831 .

(53). - Idem, de 4 de agôsto de 1831 .

(53a). - Ident, de 6 de setembro de 1831 . 
bordinados, esperando contar com êles nas ocasiões em que o apôio dos mesmos fôsse necessário para fazer uma "rusga", nome que então davam aos motins. Além disto, os solados viam a desorganização social que dominava a província; eram, em sua maioria, recrutados entre a população pobre, livre, na cidade e no campo. Sabiam que a proteção de uma autoridade poderosa livraria qualquer pessoa do recrutamento e aquêles que não conseguiam esta proteção ficavam revoltados. Os do campo sabiam ainda a impunidade que reinava no mesmo, onde os grandes proprietários, senhores absolutos dentro de suas terras, acoitavam criminosos que em certas ocasiões thes poderiam ser úteis. O próprio Harmonizador, órgão da sociedade moderada-que congregava em seu seio as figuras mais proeminentes e ricas da província, salientava esta triste situação, acrescentando que

“as próprias autoridades os soltam ou não molesta por pedido de alguém ou por dinheiro" (54).

Isto vem comprovar que encontrando o criminoso a proteção de um proprietário, êste, conforme a influência que possuia em sua região, tolhia a ação de autoridades complacentes e desonestas na perseguição ao crime, e aos poucos cada grande senhor rural possuia o seu séquito de criminosos que garantiam o seu prestígio frente aos seus inimigos. Também os Juízes de $\mathrm{Paz}$, investidos dêsse cargo por processo eletivo, tinham para poder se reeleger, que satisfazer os seus grandes eleitores, com os quais passavam a agir, perseguindo os inimigos dos mesmos, e fechando os olhos, quando não colaborando na prática de crimes, a tal ponto que aquêle mesmo jornal, de tendência visivelmente conservadora, pois combatia os que patrocinavam idéias de reforma, chegou a afirmar, no número acima citado

"Quantos pobres são perseguidos porque não consentiram que filhos ou amigos do Juiz de Paz não lhes ton:asse mulher ou filha".

Vê-se como eram pouco respeitadas as noções de honra pelas autoridades que deviam manter a ordem e evitar que se dessem crimes sexuais, pelos seus amigos e pelos poderosos do seu distrito, contra as moças e senhoras mais pobres. Rapázes de dinheiro acostumados a usarem e abusarem de suas escravas, queriam fazer o mesmo em relação às mulheres e moças pobres, porém livres, e conseguiam seus intentos graças à complacência ou à conivência de autoridades que lhes eram subservientes.

(54). - O Harmonizador, de 31 de março de 1832 . 
Ao lado dêstes fatos, viam-se os desprotegidos que recrutados para o serviço militar, passavam a perceber nos quartéis a diária de 126 réis, em péssima situação. Esta diária muitas vêzes passava meses inteiros sem ser paga e quando os soldados recebiam a importância que lhes era devida, a mesma era paga em moeda. de cobre. Sempre as pequenas importâncias eram pagas em moedas de cobre; e a moeda de cobre, chamada muitas vêzes de "xemxem", era falsificada com muita facilidade, circulando em grande quantidade. A fabricação de moeda de cobre, com menor pêso que a verdadeira, foi uma indústria largamente explorada durante o período do fim do Primeiro Reinado e início da Regència e sua circulação causou tantos transtornos, tantos incidentes, provocou tantos problemas que o assunto poderia ser estudado e desenvolvido em um pequeno ensaio. O Presidente Pinheiro de Vasconcelos, assim como seus sucessores, tomaram inúmeras medidas. para extinguir tal praga, sem resultados práticos. Só na ilha do Nogueira, próxima aos Afogados no município do Recife, foram em setembro de 1831, apreendidas por uma sortida policial duas fábricas das mesmas e, o govêrno, depois, impotente, proibiria até a venda de fôlhas de cobre, para evitar que elas fôssem parar em mãos dos falsários. O comércio freqüentemente recusava-se a receber qualquer moeda de cobre, temendo que elas fôssem falsas, - que iria colocar as pessoas de poucos haveres, entre os quais os soldados e suas famílias, que recebiam proventos nesta moeda, em situação difícil e o Govêrno determinaria constantemente que os comerciantes recebessem as moedas de cobre, sem conseguir impor a sua autoridade. Isto naturalmente inquietava a tropa que devido o mal estar reinante em tôdas as classes não se achava muito disciplinada.

O Brigadeiro Paula, sempre vigilante e inquieto com o atraso do pagamento dos soldos, o que podia levar os soldados à rebelião, procurou estabelecer para a tropa uma disciplina mais severa, inclusive determinando que os portões dos quartéis fôssem fechados depois das 20 horas, quando se procederia à chamada nominal dos soldados (55). Ao lado disto, nos casos de indisciplina, costumava-se aplicar castigos corporais. Assim iam os dias correndo normalmente até que a 14 de setembro, às 21 horas, os soldados do $14 .^{\circ}$ Batalhão se levantaram, dando morras ao Brigadeiro Paula $e$ aos castigos que thes eram infligidos. O Comandante do Batalhão compreendendo a precariedade da situação, procurou imediatamente o Comandante das Armas, cientificando-o do que

(55). - Relatório apresentado pelo Brigadeiro Francisco de Paula e Vasconcelos ao Presidente da Província, "Diário de Pernambuco", de 23 de setembro de 1831. 
se passava e êsté veio ao campo, tentando falar aos amotinados. Os revoltosos receberam-no com uma descarga. Resolveu então 0 . Brigadeiro Paula determinar ao comandante do $14 .^{\circ}$ Batalhão que permanecesse entre os seus soldados, procurando conter os excessos: e chamar à ordem os mais cordatos, para com êles iniciar a reação, enquanto o seu Ajudante de Ordens iria ao Quartel do $13 . .^{\circ}$. Batalhão, a fim de trazê-lo para abafar o levante. Ele se dirigiu pessoalmente ao Palácio comunicando ao Presidente o que se passava. O auxílio do $13 .^{\circ}$ porém falhou, pois quando o Ajudante de Ordens do Comandante das Armas chegou ao quartel do mesmo, já a tropa amotinada ganhara a rua.

Compreendendo não dispor de gente para a reação nos bairros de Santo Antônio e Boa Vista, partiu o Brigadeiro Paula para - Quartel de Cinco Pontas e reuniu 20 soldados de Polícia que ali estavam destacados e alguns paisanos que se apresentaram e,. compreendendo serem minguadas as suas fôrças, recuou para os Afogados onde esperava reunir tropa suficiente para fazer a reação. No Quartel das Cinco Pontas foi decisivo o apôio do Capitão João Francisco de Melo, que por sua ordem, mandou "tocar arrebate de guardas e sinos" (56) para reunir as pessoas que se dispunham a combater. O recúo para os Afogados foi uma medida de precaução porque os rebeldes sabendo de sua presença, ali, partiram em direção ao Forte, com tropas muito superiores às. que êle contava. Com êle se retiraram para os Afogados, o Capitão José Francisco Vaz do Pinho e Carapeba, que teria atuação. destacada e perderia a vida na guerra contra os cabanos, o Secretário do Govêrno Vicente Tomás Pires de Figueiredo Camargo e o Juiz de Paz de Santo Antônio. Aí, reuniu êle os habitantes da povoação, e preparou suas fôrças para, na manhã seguinte, marchar contra os amotinados. Os rebeldes, senhores do centro da cidade, se dirigiram ao campo do Erário, onde assaltaram o Laboratório e retiraram do mesmo as munições e armas que lá se achavam, tocando fogo logo após, no edifício. As peças de artilharia foram colocadas em vários pontos dá cidade e os grupos passaram a percorrer as ruas dando morras ao Comandante das Armas. Os oficiais que procuravam acomodar os mesmos, foram por êles expulsos do seu meio e a revolta não contou com o apôio de nenhum oficial. A cadeia foi arrombada e os presos libertados. Muitos escravos julgando haver chegado a hora da liberdade, confraternizaram com a tropa e a cidade ficou inteiramente à mercê dos rebeldes. Entre êles, porém, não surgiu um chefe, um líder que procurasse as autoridades e apresentasse suas reivindicações, que fi-

(56). - Relatório citado. 
zesse as exigências julgadas necessárias. A tropa dispersou-se, e aos grupos, passou a arrombar portas de casas comerciais e a saqueá-las. Inúmeras foram as tabernas assaltadas e as bebidas alcoólicas consumidas largamente, fazendo com que muitos dos rebeldes abandonassem as armas e fôssem quietamente curtir a bebedeira em casas de meretrizes, pois nestas casas, passada a luta, foi encontrada grande parte das mercadorias saqueadas. A falta de orientação dos rebeldes era tamanha, que o Presidente permaneceu em Palácio durante os três dias, tomando algumas deliberações, como promover a reunião do Conselho de Govêrno, para o đia 15 pela manhã e

"expedir um Oficial de Marinha e outro de tropa de linha à Fortaleza do Brum para tirar muniçóes e conservá-las no mar, a fim de fornecer aos cidadãos, em qualquer ponto; que se reunissem" (57).

Esta medida não foi executada porque, como êle mesmo informa em seu relatório à Regência,

"os da guarnição da Fortaleza, fingindo não conhecer-me a letra, impediram que sahissem as munições, e até retiveram prêsos por algumas horas os dous Officiaes".

Mas a reação não se fêz esperar. O interessante é que ela não teve apenas um chefe e um ponto só de onde partir. Foram feitas ao mesmo tempo três reações, uma partindo dos Afogados, chefiada pelo Brigadeiro Francisco de Paula; outra no Bairro do Recife, chefiada pelo Intendente de Marinha, Capitão-Tenente Antônio Peóro de Carvalho; e, finalmente, uma terceira, em Olinđa, onde o Coronel de 2a. linha, Francisco Jacinto, rico senhor de engenho, assumiu o comando após a reunião de gente, feita pelo Major José Maria Idelfonso e o Coronel Borges Leal.

O Brigadeiro Paula, como relatou em circunstanciado ofício ao Presidente (58), na manhã do dia 15 partiu dos Afogados para as Cinco Pontas, pelo atêrro. Aí eram esperados por 400 rebeldes com uma peça de artilharia e ao se aproximarem os atacantes, receberam os mesmos atirando e gritando que desejavam paz. Dellse, então, a confraternização abraçando-se soldados dos dois grupos. Compreendendo que havia sido traído, o Brigadiero de Paula e os oficiais e os poucos soldados e paisanos que lhe eram fiéis, trataram de fugir para o ponto de partida - Afogados - enquan-

(57). - Relatório apresentado à Regência pelo Presidente Pinheiro de Vasconcelos, Mss da Biblicteca Pública do Estado.

(58). - Relatório citado, "Diário de Pernambuco", de 23 de setembro de 1831. 
to eram perseguidos aos gritos de "morra os colunas" e "fora os colunas". Reinstalado em Afogados, resolveu comunicar o que se passava ao Presidente, servindo de mensageiro o Juiz de $\mathrm{Paz}$ José Felix de Sousa. Aí êle receberia o apôio do Padre João Barbo-. sa Cordeiro, jornalista liberal que redigia a Bússola e dos Capitães João e Francisco Inácio Ribeiro Roma.

Compreendendo ser pouco segura a posição dos Afogados, retirou-se para a Boa Viagem, onde passou a tomar com urgência, as medidas julgadas necessárias, como determinar que os comandantes das milícias marchassem com as fôrçes de que dispusessem, providenciou a remessa de pólvora que existia na Fortaleza de Gaibú e exigiu dos Juízes de Paz os socorros necessários, inclusive chumbo e papel. A vantagem de Boa Viagem era dispor de meios de comunicação com o interior, por terra e por mar. Daí expediu ao Cabo, a fim de trazer o Batalhão de lá, o Capitão Francisco Roma, enquanto João Roma era enviado com o. mesmo fim, à Casa Forte. Só ao meio-dia de 16, julgou-se o Brigadeiro Paula em condições de iniciar a reação, começando por atacar os Afogados, que se achavam em poder dos rebeldes. Contava, então, com 100 homens de Cavalaria que colocou sob o comando do Capitão Carapeba e 200 de Infantaria que confiou ao Č́pitão Melo. Avançou sôbre Afogados que foi ocupado sem luta e grande número de amotinados apresentou-se jurando fidelidade e oferecendo-se para lutar contra os rebeldes. Por sua ordem, o Alferes João Gonçalves de Carvalho dividiu os mesmos em dois grupos, ficando um prêso, enquanto o outro era levado para o quartel. Tal medida visava impedir que nova surprêsa desagradável como a de Cinco Pontas, no dia 15, viesse a acontecer. Aí, também, soube o Brigadeiro que na Boa Vista, o Coronel Francisco Jacinto Pereira, acompanhado de outros oficiais e de muita tropa, estava pronto a penetrar na cidade. Enviou, ao mesmo, um emissário, para combinar a entrada conjunta, mas êste voltou com a notícia de que a cidade já fôra ocupada pelo referido Coronel e que os rebeldes já haviam sido vencidos. Ele, então, entrou no Recife, sem luta.

No beirro do Recife, a luta fôra intensa; no próprio dia 14, às 21 horas, o Capitão-Tenente Antônio Pedro de Carvalho, como informa em ofício ao Presidente (59), notou uma reunião de muita gente no Arco da Conceição e compreendendo que se tratava de alguma anormalidade, foi ao arsenal, reunindo pessoas que the eram fiéis e entrou em contacto com o Juiz de Paz do Recife. Para impedir comunicação entre êste bairro e o de Santo Antônio,.

(59). - Diário de Pernambuco, de 23 de setembro de 1831. 
por compreender que naquele já a revolta se tornara mais séria, desejou cortar a ponte, a machado, mas encontrou forte oposição dos que the eram fiéis que alegavam tratar-se apenas de uma luta entre soldados .Comunicou, então, o fato ao Presidente, por intermédio de um escaler e como fôsse informado de que êste enviara à Fortaleza do Brum, o Tenente José Maria Wandenkolck, a fim de retirar cartuxame, instou com o povo para que continuasse reunido, aguardando os acontecimentos. $O$ povo, porém, alegando nada mais haver, dispersou-se.

Na manhã do dia 15, resolveu êle tomar conhecimento da situação e notou que "os malvados" estavam arrombando casas na rua do Arco da Conceição, procurou, então, e conseguiu reunir gente de Fora de Portas, recebendo também o apôio de 50 acadêmicos do "Curso Jurídico" que tinham vindo pelo istmo, da cidade vizinha, onde haviam se apresentado ao comandante militar Cel. Borges Leal. Esta fôrça, vinda de Olinda, se compunha, como relata o Olindense $(60)$, de

"Alguns 50 estudantes, uns poucos milicianos do Recife, outros de Olinda, e alguns paisanos, montando tudo a 70 pessoas, pouco mais ou menos, foram 2.0 Forte do Brum, onde encontraram os bravos Tenente José Pedro $e$ Capitão José Maria; o destacamento de linha da Fortaleza os abraçou como irmãos e assegurou que nunca se bandearia ao partido dos ladróes que saqueavam a capital; os estudantes e seus companheiros, fiados nessa pro. messa, deixaram aquêles oficiais na Fortaleza com o destacamento e marcharam para o Recife a atacar os amotinados, reuniram-se ao intendente de Marinha, que com alguns marinheiros, tinha postado duas peças de navio no Arco de Bom Jesus".

Fortificado aí, ordenou a dois oficiais que fôssem com alguma tropa explorar as ruas do Bairro do Recife, tentando impedir novos arrombamentos. Compeendendo a situação, os rebeldes os atacaram, e ao reagir, viu-se o Intendente de Marinha, traído por

"30 soldados de policia e 12 da Guarda do Arsenal",

viu-se colocado entre dois fogos. A tropa atemorizada dispersou-se. Entre os que tombaram achava-se um estudante do Curso Jurídico que, infelizmente, não conseguimos identificar. $\mathrm{Na}$ opinião do Major Domingos Codeceira, êste estudante foi o $3 .^{\circ}$ anista Galdino Agostinho de Barros, indo de encôntro a Pereira da Costa e a Maximiliano Lopes Machado, que dizem ter o mesmo

(60). - O Olindense, em "Contribuição à História da Imprensa Brasileira", de Hélio Vienna. Rio de Janeiro, Imprensa Nacional, 1945. 
falecido na Abrilada (61). Como aquêle historiador faz a sua afirmativa, sem apresentar o documento que the serviu de base, e como não encontrássemos nenhum documento da época que declarasse o nome do herói, deixamos em branco a afirmativa. Sabemos, entretanto, que um dos estudantes do Curso Jurídico que lutou contra os setembristas e, no ano seguinte, contra os restauradores da Abrilada, foi Joaquim Nunes Machado, que se destacaria como a principal figura da Revolução Praieira, perdendo a vida a 2 de fevereiro de 1849, em defesa dos seus princípios. Com a debandada, os estudantes recuaram para a Fortaleza do Brum e encontraram os portões da mesma fechados. E' que

"o destacamento que a ocupava se revoltou contra os officiais que faziam fogo sobre os amotinados que pela ponte passavam para o Bairro do Recife” (62).

Tentaram os rebeldes um ataque ao Armazém da Intendência, como já haviam feito ao Laboratório e ao Trem, visando apossar-se da artilharia ali existente. Entrou, então, em ação o Paquete Feliz, que se achava próximo ao mesmu e evitou mais esta derrota para o Govêrno. Mas os rebeldes da Fortaleza do Brum, vendo seus companheiros donos do bairro, saíram da mesma para saquear e beber nas ruas da cidade. Aproveitaram a oportunidade os estudantes do Curso Jurídico que se achavam na Fortaleza do Buraco, comandados pelo Capitão-Tenente Pedro Antônio, graças a um aviso do Coronel Salgueiro, que nela se achava, de a tomarem aos poucos que a guarneciam. Determinou então o Intendente que a escuna de guerra Rio da Prata, "que fundeara na tarde anterior", entrasse no pôrto e, passando às ruas, cavou trincheiras no Arco da Conceição. Dominava assim o Bairro do Recife, a 16, quando o Coronel Francisco Jacinto chegou ao de Santo Antônio (63).

Mas como conseguiu o Coronel Francisco Jacinto libertar a cidade? Com que fôrças contava êle? Vejamos a sua atuação na Setembrizada, para melhor compreendermos os fatos que se sucederam a esta sedição. Esta reação, como sabemos, partiu de Olinda e foi organizada pelo Comandante Militar da Cidade, Borges Leal, que sabendo ser pouca a munição de que dispunha, apesar de contar com muitos milicianos, retirou do Forte do Buraco, 740 cartuxos (64) e

(61). - Pereira da Costa, Anais Pernambucanos, parte inédita e Maximiliano Lopes (62). - Machado, O 14 de ab Olindense, op. cit.

(63). - Manue1 Correia de Andrade, Os estudantes de Olinda e a Setembrizada, "Anuário de Olinda". Olinda, 1953.

(64). - o Olindense, op. cit. 


\begin{abstract}
"mandou dois estudantes em uma jangada pedir munição no paquete inglês, mas estando o comandante emn terra, foi preciso alcançar ordem por escrito do cônsul, e não se pôde utilizar, porque com demoras inevitáveis, jor causa dos baixos e pedras, só no dia 16 chegaram 12 armas e mil cartuchos".
\end{abstract}

\title{
Na tarde do dia 16 , relata o Olindense
}

"o sr. Coronel Francisco Jacinto, ex-Comandante Interino das Armas, veiu a Olinda, reuniu alguma gente e dirigiu-se à capital, pela Bôa Vista, tendo entrado mesmo de noite na cidade, por não achar resistência, viu-se obrigado a retirar, porque os soldados que o haviam recebido fraternalmente, se revoltaram contra êle grifando morra tudo que é paisano. No dia 16 , a tarde, entrou na cidade o sr. João Roma à testa de 80 a 100 homens, que ajuntou na Casa Forte, e logo entrou o Sr. Francisco Jacinto com 300 a 400 homens, os amotinados se foram reunindo no logar do Palácio Velho, e ahi, a um sinal dado pelo sr. Presidente por meio de uma bandeira, foram atacados ao mesmo tempo pelo Forte do Brum, pelo sr. Francisco Jacinto e pela gente do Recife, que se tinha reunido na ponte, inteiramente dispersos".

Interessante é a maneira como o Presidente, em seu relatório, -descreve o fim da Setembrizada, informando ao Ministério que, ao saber da ocupação da Fortaleza do Brum pelos acadêmicos

"Logo comuniquei ao Comandante das Armas e ao referido Coronel Francisco Jacinto que entrassem com a sua gente a Fortaleza do Brum que já se achava livre e ocuparla pelos paizanos principalmente estudantes do Curso Juridico que, quando do Campo do Erario a tropa de linha rompesse fogo contra os paizanos e apparecesse no telegrapho bandeira encarnada, fizsse fogo aos rebelcies. Estes se conservaram no dito Campo, de murrões accesos e os que se espalhavam pela cidade já começavam a ser presos e remettidos para bordo das embarcações".

"O Corpo de paizanos do Coronel Francisco Jacinto, repellindo os que encontrava na sua marcha, cntrou nesta praça as duas horas da tarde e foi recebido com o maior enthusiasmo; ordenei-lhe que se conservasse em boa orRem e esperasse a chegada do Commandante das Armas para então intimar-se aos sediciosos de se renderem, visto que estavam sitiados e só num caso de ataque fizesse investir o campo. Neste momento rompem os sediciosos o fogo de artilharia para o Palácio e Ponte do Recife, onde havia uma guarda avançada de paizanos e milicianos. o que deu motivo ao dito Coronel investir com os seus e com a guarda avançada da Ponte, e triunfando o amôr -da pátria tomaram as peças e prenderam a maior parte 
dos sediciosos já esmorecidos pelo fogo que também soffreram da Fortaleza. E assim ficou livre a cidade de taes monstros. Então começava a entrar pela parte do sul o Commandante das Armas com os seus, trazendo na retaguarda uns trinta soldados que tinha feito prender, e pondo na vanguarda setenta de quem se não confiava, por terem sido uns e outros do numero dos sediciosos, e entrando na Praça se repetiram os vivas a Nação Brazileira, a Assembléia Geral, ao Imperador, aos heroicos Pernambucanos e a elle".

Mas que fizeram na Praça durante o tempo que a ocuparam, os rebeldes? Por que não ofereceram resistência séria aos defensores da legalidades, quando êstes marcharam sôbre a mesma? Por que não prenderam o Presidente e seu Conselho que estiveram em Palácio, quase desguarnecidos durante os três dias em que êles foram senhores da cidade? Da leitura do Relatório do Presidente à Regência e dos ofícios enviados pelas várias autoridades a êste, podemos concluir que a sedição surgiu expontâneamente, sem nenhuma preparação anterior no meio da tropa e que, contaminando a maioria das tropas de 1a. linha, levou-as ao domínio da cidade. Não possuindo chefes e não havendo dentre êles um líder, não formularam exigências ao govêrno que enfraquecido e sem o domínio da cidade, certamente os atenderia. Por isto, sem saber porque se haviam levantado e sem contar com um chefe, os setembristas passaram a saquear a cidade, assaltando lojas de onde retiravam mercadorias, e tabernas onde conseguiam bebidas alcoólicas. Furtando e embriagados, perambularam pelas ruas até que cansados deram tempo a que as fôrças legais se organizassem, marchassem sôbre a cidade e os dominassem, aprisionando-os. O roubo foi o que mais os preocupou, quando se viram donos da cidade, apesar de haverem se rebelado apenas contra as medidas disciplinares do Brigadeiro Paula, e

"Foram arrombadas e roubadas no Bairro do Recife nove lojas e quatro tavernas; neste de Santo Antònio trinta e três lojas e vinte e uma tavernas e no da Boa Vista três tavernas" (65).

Sôbre a atitude dos rebeldes, quando senhores da cidade, é interessante o depoimento do próprio Presidente,

"não era possivel tratar com os rebeldes que, senho." res das armas e espalhados em grupos por toda a cidale, nada exigiam; não tinham chefe, e nem o levantaram".

(65). - Relatório do Presidente da Provincia, etc., op. cit. 
O Olindense estranharia a ausência absoluta de qualquer ofi"cial entre os sublevados e não compreendemos porque se queira, hoje, atribuir a esta revolta, um sentido restaurador, comparando-a à Abrilada e à Guerra dos Cabanos.

Para se compreender o vulto, o número dos revoltosos e as perdas impostas à Província, é, ainda, interessante ouvir o Presidente Pinheiro que informa

"Existem presos a bordo das embarcações e guardalos pela Escuna Rio da Prata (que por este motivo fica aqui retida) para mais de mil pessoas entre soldados, criminozos, que estes soltaram, e gente da infima plebe que se lhes tinha reunido, todos em flagrante delito, uns porque faziam fogo e eram encontrados com as armas na majo, e outros por serem apanhados com roubos. O numero dos mortos não pode ser com exatidão avaliado porque logo se dava sepultura aos cadaveres; contudo affirma-se que dos sediciosos chegaria a cem, e dos cidadãos entre os assassinados por occasião do saque e os que se bateram contra elles, chegaria a trinta e muitos feridos, alguns dos quaes levemente".

O Capitão José Maria Ildefonso Jácome da Veiga Pessoa em ofício ao Comandante das Armas, conta que os amotinados se limitavam a gritar pelas ruas

"fora os colunas, fora o castigo da espada, fora o Brisadeiro, fora os marinheiros; viva D. Pedro II, vivão os Brazileiros" (66).

E' interessente ressaltar como êles estavam desorientados, pois davam gritos contra o Brigadeiro, chefe federalista, e herói do 7 de abril, e contra "colunas" e "marinheiros" que eram justamente os portuguêses, que para êles encarnavam a volta de $D$. Pedro I. Assim êles queriam lutar contra absolutistas e liberais, contra partidários de D. Pedro I e de D. Pedro II, a quem inconscientemente aclamavam. Estes fatos nos levam a crer mais uma -vez, que esta rebelião não tinha fins premeditados, que foi apenas um motim de soldados indisciplinados, que não queriam se submeter às determinações do seu comandante, como afirmava o Diá:rio de Pernambuco de 30 de setembro de 1831.

Um problema que diz respeito à Setembrizada e que tem preocupado sobremaneira os intelectuais pernambucanos, como Alfrede de Carvalho e Sebastião Galvão e, modernamente, Amaro Quintas, é o da ligação do nome da praça Chora Menino aos episódios da Setembrizada. O primeiro afirma

(66). - Ofício do Capitão José Maria Ildefonso Jácome da Veiga Passos ao Coman-: dante das Armas, "Diário de Pernambuco", de 1." de outubro de i831. 
"ser tradição que por ocasião da formidável revolta militar havida no Recife, em 14, 15 e 16 de setembro de 1831, foi massacrado grande número de soldados amotinados no lugar que ainda hoje conserva aquella denominação" (67).

O segundo tem significativa passagem sôbre o assunto em seu Dicionário Corográfico, Histórico e Estatístico de Pernambuco, quando afirma que dizem estar ligada à denominação Chora $\mathrm{Me}$ nino a seguinte lenda:

"Em 1831, depois do saque que a tropa da guarnição da cidade insubordinada, fez na revolta conhecida por Setembrizada, os soldadus e vários indivíduos máos, associados aquelles, não só arrombavam as casas e as roubavam mas violando os lares, commettiam toda a sorte de atrocidades e mortes. Foram nessa paragem enterradas muitas d'aquellas victimas fallecidas. Então os visionarios, que alta noite passavam por alli, diziam ouvir, sem. ire choros de menino".

Este assunto sempre me interessou, mas nos documentos da época, por mim pesquisados, em jornais e manuscritos existentes na Biblioteca Pública do Estado e em outros lugares, nada encontrei que orientasse neste sentido, nada que provasse as afirmações daqueles mestres, nem a "tradição" citada por Afonso de Carvalho, nem a "lenda" de que fala Sebastião Galvão. Apenas em seu relatório, o Presidente da Província assevera que

"o numero dos mortos não pode ser com exatidão avaliado, porque logo se dava sepultura aos cadaveres"

Seria que êles eram sepultados na campina do Chora Menino que se situava, então, em zona afastada da cidade? Não se pode afirmar, por isto continua de pé a suposição. Não é provável que tenha havido luta naquele local, porque estava muito distante da cidade, onde os rebeldes dominaram, devendo-se saiientar que mesmo a Boa Vista sofreu pouco a ação predatória dos mesmos, onde apenas três tabernas foram arrombadas e onde esteve, no próprio dia 15 , quando a revolta estava no auge, o $\mathrm{C}-$ ronel Francisco Jacinto.

Passado, porém, o período de lutas, sérios problemas teriam que ser enfrentados. O primeiro foi a prisão dos sublevados que foram encaminhados para as praias e destas para os navios surtos no pôrto, sob a guarda da escuna Rio da Prata que era comandada

(67). - Alfredo de Carvalho, Anais da Imprensa, etc., op. oit. 
pelo tenente Marques Lisboa, futuro marquês de Tamandaré (68). Posteriormente êles seriam enviados ao arquipélago de Fernando de Noronha, pois a maior distância do continente, assegurava maior garantia à população.

Sôbre a apreensão das mercadorias roubadas, também o Presidente tomou sérias providências, comunicando à Regência

"Mandei fazer depositos em todos os bairro's para recolher a fazenda roubada e algum dinheiro que tambem se descobrio, e ainda a policia trabalha nesta diligencia debaixo das ordens do Ouvidor Geral do Crime e dos iuizes de Paz, e fiz espalhar circulares pelos de beira mar para aprehenderem a que aportasse pelos seus districtos em jangadas e canôas, e bem assim pelos do centro, em alguma se tem aprehendido.

Fico na diligência de vêr si os roubados, conforme propoz o referido Ouvidor do Crime, nomeiam alguma commissão de entre sí para tomarem conta de tudo e fazerem o dividendo, segundo lhes parecer mais justo, visto não ser possivel entregar a casa um o que era de sua propriedade.

Os juizes ficaram trabalhando nos corpos de delicto, para depois instruir-se os competentes processos".

Apesar destas providências, a população permanecia sobressaltada, temendo novas dificuldades e riscos, como os que sofrera nos três dias da revolta, principalmente por saber a inexistência de tropa de linha que fôsse fiel ao govêrno. Quase tôda ela participara da rebelião. A situação tornou-se tão séria, que os cônsules estrangeiros, de acôrdo com os comerciantes dos seus países, aqui estabelecidos, chegaram a enviar enérgica nota ao Govêrno, pedindo que informasse qual o destino que pretendia dar aos presos, pois julgavam seus patrícios sem garantias, por correr na cidade o boato de que os mesmos seriam soltos, e responsabilizavam ao Govêrno pelo que viesse a acontecer aos seus súditos, se tal boato fôsse confirmado pelos fatos. Esta atitude do corpo consular, ao nosso ver, era uma afronta ao Govêrno, mas êste, profundamente fraco, destituído de autoridade, limitou-se a garantir que os presos não seriam libertados, mas punidos (69). A conspiração era geral e ninguém confiava na tropa, por isto resolveu o Presidente que os presos seriam remetidos para Fernando de Noronha, só permanecendo no Recife, aquêles cuja conduta fôsse abonada por oficiais, os quais ficariam inteiramente responsáveis pelas atitudes rebeldes que os mesmos tomassem (70). Claro que muitos pou-

(68). - Gustavo Barroso, Tamandaré, o Nelson Brasileiro. Rio de Janeiro, Editôra (69). - Diário de Pernambuco, de 28 de setembro de 1831.

(70). - Idem, de 6 de outubro de 1831 . 
cos conseguitam o desejado abôno e em conseqüência, devido à falta de fôrças, a guarda da cidade passou a ser feita pelos sidadãos (71) e a Câmara deu ordem para que multasse aquêles que não se alistassem nas Guardas Municipais, ou que, alistados, faltassem aos serviços que competiam às mesmas (72). Assim, o povo armado, ia garantir-se a si próprio e a seus bens.

Neste ambiente de insegurança intensificou-se a conspiração dos políticos. A Sociedade Patriótica Harmonizadora, que temia a ação do Brigadeiro Paula, conhecido pelas suas idéias liberais e federalistas, passou a culpá-lo pela Setembrizada, dizendo que, se fôsse um militar competente e zeloso, poderia ter impedido que ela tomasse as proporções que tomou, e tendo a frente Antônio Joaquim de Melo, levantava a suspeita de que êle fugira para a Boa Viagem, quando a situação se tornou difícil. Ao mesmo tempo procurava enaltecer a atitude do Coronel Francisco Jacinto, que marchara de Olinda com a sua gente, sôbre a capital. Não descuidou ela de antes enviar um memorial ao Presidente, no jual assegurava que

“A Sociedade Patriótica Harmonizadora trespassada de magoa pelos desastrosos acontecimentos dos dias 14, 15 e 16, promovidos por uma soldadesca insubordinada, que à maneira dos antigos vandalos saquearam a cidade estragando o que não podiam aproveitar e unindo a taes harbaridades o assassinio e o incendio, faltaria ao nobre fim da sua instituição si não viesse, quanto antes, à presença de V. Exc. não só manifestar a sua pungente dôr por tão desgraçados sucessos, como assegurar a V. Exc. que para acautelar a sua repetição de que resultaria a ruina total desta provincia, ella desde já põe a disposição de V. Exc. suas pessoas e fazendas. A Sociedade espera de V. Exc. desassombrado de qualquer boato aterralor, suggerido pela fraqueza, se convença de que os Brazileiros Pernambucanos, qualquer que seja a sua naturalidade e opiniões politicas, se reunirão sempre debaixo das ordens de V. Exc. para sustentar a Constituição que nos rege e as autoridades por ella instituidas enquanto pela Assembléia Geral dos Represntantes da Nação não for por outra maneira legislado, e de que, si por desventura nossa a anarchia quizer levantar o seu medonho cólo na patria dos Vieiras, Vidaes e Dias, o berço da liberdade Prazileira, ella será suplantada pelo valor dos seus cidaciàos, assim como acabam de o fazer com essa desemfreada soldadesca, que no furor da pilhagem não conheciam os seus mesmos officiais. De longo tempo, Exm. Senhor, a Guarda Pretoriana dos Romanos nos devia ter convencido que a segurança dos governos e conseguinte-

(71). - Idem, de 6 de outubro de 1831 .

(72). - Idem, de 14 de outubro de 1831 . 
mente a da liberdade e propriedade individual dos cidadãos só podia existir no seu patriotismo e não nessas cohortes de mercenarios arrancados muitas vezes das prisões à que tinham sido conduzidos por sua imoralidade.

Não era preciso de certo uma tão dolorosa experiencia para confirmar tão saliente verdade. A sociedade tão conhecedora quanto confiada no juizo prudencial que $V$. Exc. tem desenvolvido em todo o tempo do seu Governo, não pretende offender os conhecimentos de V. Exc. lembrando coisa alguma relativa à publica administração, mormente sendo isto estranho à sua instituição, e nada podendo escapar à perspicacia e patriotismo de V. Exc. Todavia Exm. Sr. a Sociedade não pode deixar de rogar a V. Exc. queira fazer arredar, quanto antes, de nossas praias esse bando de vandalos, afim de evitar-se que o devido odio a tão horroroso crime se converta com a de. mora do castigo em compaixão para com os criminosos, e que algum espirito invisivel, aproveitando-se desta circunstancia e da desesperação daquelles malvados, aão tente promover com o seu desembarque a anarchia, o maior mal que a natureza em sua ira gerou para dano dos mortaes".

Seguiam-se dezenas de assinaturas de sócios da "Harmonizadora", compreendendo militares, comerciantes, proprietários, senhores de engenho, funcionários, lentes e estudantes do curso jurídico, etc. (73).

Os estudantes do curso jurídico, não satisfeitos com a participação direta nos acontecimentos, enviaram um abaixo-assinado ao Presidente, com 193 assinaturas, oferecendo os seus serviços e êste, aproveitou-os, para fazer a guarnição das Fortalezas do Brum e do Buraco. A Novembrada ainda os encontraria em tal pôsto (74).

O desentendimento entre os moderados e os exaltados já se fazia sentir, contando os primeiros com os conservadores e, até, com os absolutistas, uma vez que se propunham fazer a "harmonização". Eles desconfiavam do Brigadeiro Paula e fizeram forte campanha contra o mesmo, esquecendo que êle fôra muito hostilizado durante a luta, pois, ao lado de gritos de morra aos "colunas" e aos "marinheiros", ouviam-se, constantemente, morras "ao castigo da espada" e de "abaixo o Brigadeiro Paula".

Muito desêjo de vingança, dos que foram prejudicados pelas medidas moralizadoras do ilustre militar, se fazia sentir agora. Sabendo, ainda, que o Brigadeiro não era simpatizado pelos Generais Lima e Silva, José Joaquim e Manụel da Fonseca, que do- 
minavam a regência, passaram a espalhar o boato de que, responsabilizado pelos acontecimentos de setembrọ, êle seria dimitido (75). Os Juízes de Paz do Recife e Boa Vista, sabendo da popularidade que êle gozava entre os habitantes dos seus distritos, trataram de protestar contra êsses boatos, salientando 'a confiança que o povo depositava naquela autoridade (76).

Ele, porém, teve os seus defensores, não só entre os federalistas, como entre os que, apreciando a sua atuação, julgavam-na justa, digna e oportuna para reprimir os desmandos existentes na província. O Diário de Pernambuco, por exemplo, apresentou-se logo em campo, no número de 14 de outubro, afirmando que êle não podia ser responsabilizado pelo que acontecera, uma vez que os distúrbios eram generalizados nas demais províncias do Império, apontando os que ocorreram na Paraíba, Ceará, Maranhão, Pará e Piauí e o jornal Caheté chegou a esquematizar as razões que determinaram a campanha contra o mesmo, da seguinte maneira: 1) não se haver unido aos aristocratas, que dominavam a província; 2) ser o mesmo figura proeminente do 7 de abril - o que irritava os restauradores; 3 ) haver afastado um fornecedor inescrupuloso do fornecimento das etapas da tropa, assim como, dos fornecimentos de forragens aos cavalos, no qual era $1 / 4$ de milho substituído por duas garrafas de mel; 4) ter feito recolher aos cofres dos batalhões, dinheiro e letras que os ex-Comandantes espalharam ao seu bel prazer; 5) suspender o pagamento de gratificações aos oficiais "colunas" que haviam sido afastados; 6) ter trabalhado pela volta ao serviço ativo, dos heróis de 1824 e outras atitudes de verdadeira regeneração. Assim os dois grupos em que se dividia a província continuaram a se degladiar, após a repressão aos setembristas, que iriam ser submetidos a um moroso processo, pois ainda em 26 de setembro de 1832, mais de um ano após os acontecimentos, assim se expressava o Presidente, ao então Comandante das Armas

"cumpre, que V. Sa. me remetta com a possivel brevidade um mapa circunstanciado dos Officiais, Officiais Inferiores, e Soldados, que forão pronunciados na devassa, que procedeu o Dezembargador Ouvidor do Crine desta Cidade pelo motim de setembro do anno passado, dáquelles a quem se formalizarão conselhos de investigação, e forão, ou deixarão de ser interrogados, declarando no mappa que se achão prezos, onde, e os auzentes" (77).

(75). - Idem, de 10 de outubro de 1831.

(76). - Idem, de 5 de novembro de 1831

(77). - Ofícios do Govêrno, Mss. da Biblioteca Pública do Estado de Pernambuco, 1832. 
A 23 de setembro de 1833, novamente o então Presidente dirigia-se ao Comandante das Armas, para mandar libertar e dar baixa aos setembristas que ainda se achavam presos, desde que "não tiveśsem sido sentenciados" (78).

Estava, portanto, bem dividida a opinião pública na província, quando, a 9 de outubro, aqui chegou o deputado pernambucano Francisco de Carvalho Paes de Andrade, irmão do Chefe da Confederação do Equador, que havia sido nomeado Presidente, pela Regência (79). O Presidente Pinheiro, cuja atuação era enaltecida pelos órgãos da imprensa, inclusive pelo Diário de Pernambuco, tinha seus méritos reconhecidos pelo Ministro Lino Coutinho, que the informava ser a sua demissão ditada apenas pela necessidade de se colocar na Presidência de Pernambuco, um pernambucano, o primeiro aliás, desde a independência. Acrescentava a comunicação de que deixando o Govêrno de Pernambuco fôra nomeado para igual cargo na Província do Pará. A Regência, dominada pelos moderados e desejosa de iniciar a reação contra. os homens que fizeram o 7 de abril, procurava assim, com a nomeação de Francisco Carvalho, angariar as simpatias dos pernambucanos. Este tinha em seu favor o fato de ser pernambucano, e de ser irmão de Manuel de Carvalho, que apesar do combate. que sofrera durante o Primeiro Reinado, era muito prestigiado na província e, ainda, a sua atuação revolucionária em 1824. Os exaltados, os federalistas, exultavam, pois não sabiam que a idade $e$. as posiçóes conquistadas haviam acomodado o espírito do novo Presidente; não compreendiam que êle não era mais o homem de: 1824. Para os federalistas, esta nomeação era uma garantia da continuação do Brigadeiro Paula, no comando das Armas, e redobravam a defesa do mesmo e o ataque aos moderados que caminhavam para a reação. Nova ordem da Regência ainda fêz exultar os federalistas, quando determinou que os estrangeiros fôssem. afastados dos cargos públicos, sendo substituídos por brasileiros. e que tal međiida seria aplicada também aos militares que não estivessem enquadrados na lei de fixação de fôrças, de 25 de novembro de 1830 .

Ao mesmo tempo o Bispo D. João Perdigão, que participaria da pacificação dos cabanos em 1835, alarmado com a situação da província, ordenou em pastoral (80) aos padres da diocese, que ao pregarem a doutrina cristã, aos domingos e dias santificados, chamassem a atenção dos fiéis para o fato de que

(78). - Ibidem, 1833

(79). - Diário de Pernambuco, de 11 de outubro de 1831.

(80). - Pastoral do Bispo D. João Marques da Purificação Perdigão, "Diário de Pernambuco", de 10 de outubro de 1831. 
"a obediência, e respeito às autoridades constituidas he o nexo essencial da sociedade civil, formada para os fins para que Deus a creou".

Afirmava deverem os sacerdotes fazer ver aos crentes que deviam cumprir as leis e evitar a indisciplina, afirmando ainda na pastoral

"Comprovai-lhes esta asserção, com os exemplos de Jesus Christo, o qual sabendo que a obediência, a veneração as leis, que o Govêrno deve manter, e por meio dos quais somente podemos prosperar, hera de absoluta necessidade, a estas se sujeitou, estas respeitou, e fez resneitar afim de nos exemplificar".

Assim, o Bispo, português de nascimento, se solidarizava com o Govêrno nos momentos difíceis porque passava, ordenando aos padres que em seus sermóes, ao lado dos ensinamentos religiosos, fizessem doutrinação política em favor do mesmo Govêrno.

\section{A SOCIEDADE FEDERAL.}

As lutas políticas e discussões ideológicas se intensificavam cada vez mais, sendo a imprensa o veículo por onde elas constantemente se manifestavam. Os elementos mais radicais, que desejavam a federação das províncias, para que as mesmas gozassem de mais autonomia dentro do Império, queriam que uma reforma constitucional consagrasse êste princípio, tendo na palavra "federação", forte barcieira de luta. Os mais extremados chegavam a desejar a Fečeração ou até mesmo a república de qualquer forma, por qualquer meio. Os absolutistas e os moderados, que apesar de liberais, vinham no fim do Primeiro Reinado fazendo concessões ao govêrno do Primeiro Imperador e que temiam qualquer mudança substancial no regime, em seus jornais, identificavam a todos os reformistas e os apontavam ao povo simplesmente como seus inimigos, como anarquistas.

No Rio, a reação monárquica ia se processando vagarosamente. Os exaltados que haviam feito a mais vigorosa oposição a $\mathbf{D}$. Pedro I e que haviam participado, com grande risco, das agitações de rua, que haviam, finalmente, levantado o povo e preparado a famosa concentração de 7 de abril, se viram, ao se consumar a vitória, esbulhados pelos moderados, que contando com maior número de deputados e senadores e tendo o apôio das tropas do General Lima e Silva, que momentos antes aderira ao movimento, se apossaram da Regência. A princípio, quando os partidários de 
D. Pedró ainda mereciam certo temor, e o apôio dos exaltados era necessário, deram aos mesmos alguns postos importantes que, posteriormente, ao se verem senhores da situação foram retirando. A êste princípio obedeceu, certamente, a indicação do Brigadeiro Francisco de Paula e Vasconcelos, para o Comando das Armas de Pernambuco. Este militar era conhecido por suas idéias liberais, - das quais compartilhava também o seu irmão, o Major Miguel de Frias e Vasconcelos -, e se notabilizara por haver sido o primeiro oficial general que saira com os seus subordinados, quando o povo se reuniu no Campo de Honra, em 6 de abril, chegando ao mesmo, antes da situação se definir. Depois, outros oficiais, inclusive os irmãos Lima e Silva, tomaram idêntica atitude. Vitorioso o movimento, resolveu a Regência enviá-lo a Pernambuco. pois era um pôsto de importância e êle certamente aceitaria, pois sabia ser esta província um lugar onde D. Pedro colocara seus mais intransigentes partidários e poderia exercer, na mesma, uma ação saneadora. Com a vinda do Brigadeiro, para Penambuco, cortava a Regência o contacto existente entre êle e os federalistas do Rio, impedindo que em caso de luta, liderasse os mesmos, como. faria o seu irmão. Afastou do centro, da Côrte, um inimigo em potencial. Depois seria mais fácil eliminar a sua influência na província nordestina. Os pernambucanos sabiam das idéias do Brigadeiro que apesar de viver muito preocupado com seus afazeres: militares, não escondia seus pontos de vista. Os conservadores, agora organizados na Sociedade Harmonizadora, combatiam os federalistas, intransigentemente, demonstrando serem favoráveis ao unitarismo do Império, embora geralmente não o confessassem.

$O$ auge da luta se acenderia com o anúncio publicado no Diário de Pernambuco do dia 15 de outubro, de que no dia seguinte, às 10 horas, se instalaria no Consistório da Igreja da Conceição dos Militares, a Sociedade Federal, em sessão pública, para que o povo tomasse conhecimento dos seus fins. A indignação não só dos "colunas", como também dos moderados, chegou ao auge. A Câmara Municipal do Recife, sob a direção do seu Presidente, o "harmonizador" Antônio Joaquim de Melo, chegou a oficiar ao Govêrno e pedir às outras Câmaras Municipais que assim procedessem, solicitando o fechamento da Sociedade e a perseguição de seus membros - entre os quais estavam o Comandante das Armas e vários oficiais superiores -, por ser a mesma, em sua opinião, anárquica e revolucionária, querendo, dizia, por meios ilegais, modificar a Constituição do Império. O Diário de Pernambuco, de 19 de outubro, combateu tal pretensão dizendo serem res- 
ponsáveis pela "cabala", a Sociedade Patriótica Harmonizadora e"um certo Sr. Antônio Joaquim de Melo".

A situação era tão tensa que João Ascânio Barbosa, Juiz de Paz do Santo Antônio, compareceu à sessão inaugural e a 20 de outubro, publicou um edital no Diário de Pernambuco, acalmando o povo, prometendo comparecer a tôdas as sessões para vigiar a sociedade, garantindo que agiria contra a mesma, logo que ela se encaminhasse para a ilegalidade. Todos pareciam amedrontados, apesar de comprecerem à sessão do dia 16 e se fazerem sócios, o Brigadeiro Francisco de Paula, Comandante das Armas, os: Capitães Manuel Joaquim de Oliveira, comandante do $14 .^{\circ} \mathrm{Ba}-$ talhão, José Francisco de Melo, José Maria Ildefonso, José Joaquim da Fonseca Capibaribe e José Vaz do Pinho e Carapeba, além de lentes do Curso Jurídico, como João José de Moura Magalhães: e Manuel José da Silva Pôrto, grande número de estudantes, entre os quais podemos salientar, João Lins Vieira de Cansanção - futuro Visconde de Sinimbú e primeiro Ministro do Império. -, e Joaquim Nunes Machado que seria uma das mais atuantes figuras da política pernambucana na primeira metade do século passado. Dela também participaram os irmãos Carneiro Machado Rios - Antônio, Joaquim, Francisco e João - que teriam forte atuação na política pernambucana, promovendo até uma série de. rebeliões conhecidas como as Carneiradas (81).

A sessão foi realizada na presença de grande número de expectadores, tendo usado da palavra, para expor os fins da sociedade, a pedido dos sócios, o Dr. João José de Moura Magalhães, que. salientou visar a mesma a discussão dos fatos que atestam a necessidade da federação, salientando que os meios a serem estudados para a realização de tal idéia visavam o alcance das mesmas, através de atitudes que não violavam as leis vingentes: Nesta ses-são foram eleitos, respectivamente Presidente e secretário da Sociedade, o Padre João Barbosa Cordeiro e José Tavares Gomes da. Fonseca:

Sabendo da campanha que contra a Sociedade era movida, enviaram um ofício ao Presidente, comunicando a instalação da mesma e êste respondeu em ofício que transcrevemos

"Foi presente a este Governo a participação, que a Sociedade denominada federal the fez de sua instalação, e de que seus fins, votos, e trabalhos serão sustentar a literdade Brazileira, propalar idéias claras, e exatas à respeito do Sistema Federativo, demonstrando suas van-

(81). - Alfredo de Carvalho, As Carneiradas, in "Revista do Instituto Arqueológico. Histórico e Geográfico de Pernambuco": 
tagens, e empregando todos os meios legaes afim de o conseguir, fazendo sentir a necessidade de emanar essa Reforma da Assembléia Geral Legislativa; protestando outrossim opor-se com todas as suas forças á quanto possa conspirar para anarquia, oferecendo-se a concorrer por todos os meios ao seu alcance, e sem poupar-se á fadigas, e sacrificios para o bom implemento, e pronto efeito das medidas, que este Governo julgar necessarias para a tranquilidade da Provincia; respeitando-se a Ley, e as Authoridades Constituidas; a vista de tão justos, e saudaveis fins, á que a sociedade se propõem, este Governo não pode deixar de louvar os sentimentos, de que ela se acha possuida de agradecer os seus generosos oferecimentos, e de esperar que ella firme em seus principios jamais se deslisará da orbita legal. Ao conhecimento da regência do Império levarei a representação da Sociedade, como ella exige".

Assim, recebia o revolucionário de 1824, a comunicação da instalação da Sociedade Federal (82).

Apesar de claramente legal, a Federal continuou na "berlinda", pois $O$ Olindense, jornal dos acadêmicos Sérgio e Álvaro Teixeira de Macedo e Bernardo de Sousa Franco, que esposavam idéias contrárias às da federação, em seu número 50 , ainda de outubro de 1831, discutiria com o Diário por caúsa da acusação por êste formulada contra a pretensão de Antônio Joaquim de Melo, que desejavam fechar aquela sociedade. Mas a Sociedade Federal teria longa vida e grande atuação na política pernambucana, mesmo depois do afastamento do Brigadeiro Paula do pôsto que êle tão bem desempenhara.

Entretanto, o govêrno continuava muito fraco, pois não dispunha sequer de tropa de linha na cidade para a sua defesa, tendo de confiar a mesma às fôrças de segunda linha, o que levava seus panegiristas a julgá-lo forte, por estar apoiado nos cidadãos (83). A fraqueza era tal que só em outubro de 1831, conseguiram enviar um navio de mantimentos à Fernando de Noronha, dando ao destacamento que lá se achava, a boa nova da abdicação, que se dera seis meses antes, ao mesmo tempo que informava não poder o destacamento lá estacionado ser substituido por outro, como de direito, por não disporem de quem fôsse substituí-lo. Só então, a 22 de outubro, foi que receberam a boa nova da anistia, os presos políticos que para lá haviam sido recambiados durante o Primeiro Reinadq, período em que o absolutismo dominava Pernambuco.

(82). - Diário de Pernambuco, de 10 de novembro de 1831.

(83). - Idem, de 21 de novembro de 1831 . 
Até novembro parecia que os federalistas dominavam a política pernambucana, enquanto os moderados controlavam a Côrte e procuravam acalmar os anseios populares em favor da maior autonomia das províncias, com ligeiras reformas à Constituição que diziam, só deveriam ser feitas, lentamente e por meios estritanente legais. $O$ ideal de federação seria substituído por uma leve des--centralização, conseguida através do Ato Adicional, que seria em grande parte anulado pela chamada Lei de Interpretação. Os Lima e Silva garantiam o poder ao partido moderado, ocupando três postos chaves no Rio de Janeiro, pois enquanto Francisco era um dos regentes, Manuel Fónseca, o mais popular dos três, era Ministro da Guerra e, José Joaquim, Comandante das Armas na Côrte. Aos poucos êles foram afastando, no Rio, os exaltados, dos poucos postos de que êstes dispunham. $O$ Brigadeiro Paula, que se sa-lientara muito no 7 de abril, sendo federalista, não merecia a confiança dos mesmos e por isto fôra afastado logo para Pernámbuco, sendo neutralizada a sua influência na Côrte, enquanto esperavam um pretexto para tirar-lhe o comando desta Província. Assim, defendiam os princípios moderados de conservação da Monarquia com um mínimo de reformas à Constituição e procuravam afastar os federalistas e republicanos do poder. A eclosão da Setembrizada, embora abafada após dois dias de luta, e normalizada a vida da província - pois os problemas que afligiam Pernambuco eram. comuns a todo o país - foi o pretexto para, por uma simples portaria, o Ministro da Guerra, ordenar o afastamento do Brigadeiro do Comando das Armas em que se achava, determinando porém que permanecesse no Recife, submetido a um oficial de patente inferior à sua, além de ser de Milícias e não de 1a. linha. Tal atitude: era por êle justificada

"porque tão escandalosa e criminosa revolta militar não pode deixar de cobrir de descredito o Oficial a quem se achava confiado o Comando em Chefe da praça armada",

elogiando em seguida o Coronel Francisco Jacinto Percira

"que tanto se distinguira nos arriscados serviços a prol da segurança publica nos desgraçados dias de setembro" $(84)$.

Esquecia-se o Ministro da Guerra de que motins e sedições como aquela vinham se procedendo constantemente em tôdas as. províncias e no próprio Rio de Janeiro, sem que os comandantes.. 
das praças, inclusive o seu irmão, José Joaquim, fôssem por êle consideradas desacreditados e demitidos.

A população não recebeu com agrado a determinação ministerial e a imprensa, por seus órgãos mais importantes, criticou a mesma, não só em seu aspecto jurídico - não poderia ser demitido por uma portaria ministerial quem fôra nomeado por um decreto da Regência -, como no aspecto político, onde, dizia-se, tratar-se até de ciúmes do Ministro contra o militar de mais méritos e mais serviços prestados à pátria. Naturalmente a exaltação política levava os contendores, de lado a lado, a exageros como êste. O Diário de Pernambuco chegava ao extremo de perguntar

"Não é querer confirmar os boatos aterradores espalhados sem duvida pelos anarquistas, de que o governo quer aniguilar os agentes da gloriosa revolução de 7 de abril?" (85) .

Os federalistas, apoiados por jornais como o Diário de Pernambuco e a Sentinela Pernambucana, não se conformavam com a demissão do Brigadeiro Paula, a tal ponto que na Bod Vista chegou a ser feito um abaixo-assinado dos paroquianos pedindo a recondução ao cargo do militar que merecia a confiança do povo; entretanto, os elementos conservadores o combatiam, aplaudiam a atitude do Ministro da Guerra e chegavam a afirmar, como fêz $O$ Olindense, que ela fôra ditada pela comparação entre a atitude dêle e a do Coronel Francisco Jacinto, frente aos setembristas. $O$ Cruzeiro, órgãos dos absolutistas, fazia côro com o O Olindense no combate ao Brigadeiro, enquanto $O$ Caheté se extremava em sua defesa, chegando até a alegar que êle já se dispusera a pedir demissão duas vêzes, uma após a Setembrizada e outra após a posse do Presidente Carvalho, mas tanto êste como o Presidente Pinheiro, levando em consideração os magníficos serviços por êle prestados, recusaram-se a aceitar a dita demissão.

O Brigadeiro, porém, era militar disciplinado e não dando ouvidos às disputas dos jornais e às manifestações populares, ao ser cientificado das determinações de seu superior hierárquico, oficiou ao seu substituto, comunicando a nomeação do mesmo, pedindo que marcasse o dia e a hora em que pretendia tomar posse. o Coronel Francisco Jacinto marcou para o dia seguinte, mes comunicou ao Presidente Carvalho estar doente e não poder se demorar no cargo, pedindo ao mesmo que se dirigisse à Regência, solicitanđo urgência na nomeação daquele que o deveria substituir em caráter efetivo (86).

(85). - Idem, de 4 de novembro de 1831 .

(86). - Idem, de 7 de novembro de 1831 . 


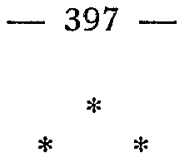

\section{A NOVEMBRADA.}

Como afirmou o Coronel Francisco Jacinto, Comandante interino das Armas, em Ordem do Dia publicada no Diário de Pernambuco de 23 de novembro de 1831, na

"noite de 15 de novembro uma força atacou a Fortaleza de Cinco Pontas e tendo superioridade numerica tomou a mesma apossando-se do armamento".

O Presidente, conforme relatório à Regência (87), teve conhecimento dêste fato às 11 horas da noite e, incontinenti, dirigiı-se a Palácio e ordenou ao Juiz de Paz de Santo Antônio

"para qué em cumprimento aos deveres de seu cargo, fosse fazer despersar aquelle ajuntamento, de que se podia seguir manifesto perigo da tranquilidade Pública, achando-se a Cidade tôda em alarma”.

Informa ainda que ao executar a ordem recebida o Juiz de Paz nada conseguiu porque os que se achavam reunidos na Fortaleza alegaram que

"querião uzar do direito de petição, concedido pela Constituição, e que tinhāo representações a ìazer",

não atendendo às alegações daquela autoridade de que êles estavam usando meios ilegais.

Começam, então, a agir as autoridades, sem energia, sem rapidez, e demonstrando uma irresolução de pasmar, uma vez que esperaram que os que estavam reunidos no forte, apresentassem suas deliberações. No dia seguinte, 16, pela manhã, foi que o Presidente conseguiu reunir o Conselho do Govêrno e êste em vez de reprimir os amotinados, limitou-se a enviar novo delegado que intimasse os mesmos a se dispersarem; sob a ameaça de proceder contra êles na "conformidade da Lei". Novamente responderam que esperassem, pois iriam usar do direito de petição, fazendo requisições ao Govêrno. E o Govêrno passou todo o dia a esperar blioteca Pública do Estado de Pernambuco. 
- esta requisição. Alegava o Presidente em seu relatório que assim procedeu, porque não dispunha de

"fôrça, para com ella despersa-los, em quanto a faziamos reunir das immediações da Praça".

Os chefes da sedição eram o Capitão Antônio Afonso Viána

"nascido em Portugal e recentemente admitido no nosso exército no seu pôsto, apesar de ter estado so serviço da República de Buenos Aires, no decırso da última guerra",

certamente a Cisplatina, e o 2. ${ }^{\circ}$ Tenente João Machado Magalhães, os quais após se apossarem da Fortaleza,

“puzeram-se em atitude hostil e, esper:ando que o partido fosse engrossando, porque os interessados na rusga andavam pelas portas a convidar gente, intrigando e mentindo como se costuma nestas crises" (88).

O Olindense, órgão bastante ligado aos moderados e partidário do Coronel Francisco Jacinto, procurou eximí-lo de responsabilidade na irresolução do Govêrno, alegando que êle

"não recebendo ordem do Govêrno para empregar a força contra os sediciosos, deu algumas providências a ver se evitava a afluência de mais gente nas Cinco Ponias, mas todas ellas foram baldadas; os piquetos com que pretendia cortar as passagens eram os primeiros a ser seduzidos e o partido ia engrossando" (89).

O grupo de amotinados se viu tão engrossado, tão forłe, com tanto apôio por parte da população, pois a Fortaleza se encheu de partidários, que quando a 17, o Juiz de Paz, João Ascânio Barbosa, reafirmou a ilegalidade da reunião, por ser feita por gente armada, respondeu-lhe o Tenente $\mathbf{M}$ cgalhães que se achavam armados apenas, os "destacamentos de artilharia de 2a. linha" e que os reunidos protestavam a "mais firme obediência às leis". Como o Juiz de Paz insistisse na ilegalidade da reunião, foi expulso da Fortaleza, pelo citado tenente, enquanto seus partidários o apupavam com gritos de "fora" "fora" (90).

(88). - O Olindense, op. cit.

(89). - Idem.

(90). Idem. 
Passado o dia 16 sem nenhuma atitude decisiva de parte a parte, em que os inimigos se contemplavam, pois nem o presiiente determinava às fôtças que reunira, $o$ ataque às Cinco Pontas. nem os levantados saíam da Fortaleza para levar a rebelião às ruas da cidade; a população ficou amedrontada, receando uma nova setembrizada e passou a se recolher com os haveres que podia transportar, aos navios surtos no pôrto. O próprio Presiderte, temendo ficar no Palácio, recolheu-se à Fortaleza do Brum, que estava guarnecida pelos estudantes do Curso Jurídico, constituindo fôrça que merecia sua inteira confiança.

Conte $O$ Olindense, que neste mesmo dia, 16, os

“cidadãos armados se ajuntaram sob as ordens dos seus Juizes de Paz, formaram-se os batalhões de milícias e todas estas forcas, montando a mais de 800 pessoas, estavam dispostas a obedecer à voz do Governo".

Diz, porém, que quando se dispuseram ao ataque, encontraram reação dos próprios reunidos, que alegavam

"Os que estão nas Cinco Pontas são brazileiros; estão encerrados dentro dos muros da fortaleza; ainda não apareceu agressão de sua parte que necessidade há de derramar sangue?"

Por causa desta atitude de grande parte das pessoas cem quem o govêrno esperava contar, foi que o Juiz de Paz da Roa Vista retirou-se com os homens que conficva para Sant'Ana e rellnindo maior fôrça, dispôs-se a voltar à cidade, a fim de perticipar da luta.

Finalmente, no dia 17 , os levantados enviaram ao Gavếrno uma petição com a assinatura de Anastácio José dos Passos, crmo procurador cie todos os reunidos, embora não apresentándo nenhum documento de procuração, fazendo as seguintes exigênẹas: a) expulsão da província, com demissão dos cargos que orupassem, se fôssem funcionários, de várias pessoas consideradas absolutistás e constante de uma grande. lista, na qual figuravam os nomes do Dr. Manuel Pedro de Moraes Meyer, do Capitão Domingos Lourenço Tôrres Galindo, do Coronel Bento José Lamenha Lins, do Tenente Coronel Francisco da Rocha Paes Barretn, Morgado do Cabo, do Major engenheiro João Bloem, assim como do escrivão Miguel Arcanjo Póstumo; b) O cumprimento da le: que manda extinguir as sociedades estrangeiras, como os Teresas e Barbones; c) expulsão dos portuguêses solteiros e inimigos da pátria esquecidos na lista, excetuando-se, apenas, "artistas, fatris 
- capitalistas de dois contos de réis para cima" e proibição de desembarque de pessoas da mesma nacionalidade que não preenchessem estas condições; d) arrecadar-se no período de 48 horas as armas nacionais que se achassem em poder dos portuguêses, mesmo milicianos. Nesta representação argumentavam que existiam sociedades perniciosas como a Coluna do Trôno e do Altar, de orientação absolutista, exclamando "digão os acontecimentos te "Setembro", como a querer culpá-la pela Setembrizada (91).

O Presidente ouviu, então, o Conselho que regeitou $a$ petição, sob duas alegações, primeiro, não possuir o procuradcr poderes para representar os reunidos e, segundo, serem as reriuisiçóes inconstitucionais.

Neste interim, vendo que os acontecimentos cada vez mais se agravavam e que era necessário alguma medida qùe pusesse fim à sedição, reuniu-se a Sociedade Federal para estudar a situação e tomar uma atitude, sendo lembrada e aprovada a idéia de ir uma comissão à Fortaleza, chamar os rebeldes à ordem. A proposta foi aptovada com forte oposição de uma parte dos sócios (92) . Diz O Olindense, que chegando a comissão à Cinco Pontas, foi recebida a

"princípio com alegria e entusiasmo, talvez por se persuadirem os amotinados que aqueles cidadãos jam associar-se a eles, mas vendo que diverso era o fim com que ali se apresentaram, esfriou esse entusiasmo e até nos dizem que apareceram alguns ditos desagradáveis, e portanto nada conseguiu a Sociedade, que voltando ao lugar de suas sessões, enviou ao Sr. Presidente uma comissão de cinco membros para pedir-lhe que assentisse a algumas das exigências dos sediciosos afim de evitar o sangue; o senhor presidente respondeu que a nada anuia".

Apesar do fracasso de sua primeira tentativa, julgou a Sociedade Federal, que devido à posição conseqüente que assumiram os partidários da federação, na revolução de 7 de abril, e em prol de maior autonomia para as províncias - anseio de grande parte da população - poderiam ser considerados insuspeitos pelos rebeldes, conhecidos como jacobinos extremados em sua maicia e atendidos nos conselhos que dessem, resolveu enviar a 18, uma comissão da qual participavam os estudantes João Lins Vieira de Cansação, o futuro Visconde de Sinimbú, e José Tomás Nabuco de Araújo Júnior, além de Francisco Carneiro Machado Rios e Antônio José Fernandes Nobre, os quais se dirigiram à Fortaleza e

(91). - Diário de Pernambuco, de 25 de novembro de 1831 .

(92). - Idem, de 23 de novernbro de 1831 . 
aconselharam os rebeldes a depor as armas e reclamar de acôr to com a lei fundamental. Estes compreendendo que dispunham de minguados recursos, pois o Govêrno tivera tempo de aliciar partidários, enquanto êles se confinavam na Fortaleza, resolveram apresentam ao mesmo três condições, mediante as quais êles se dispersạriam: a) que os portuguêses armados, em sua imensa maioria milicianos, depusessem as armas; b) que fôssem deportados aquêles portuguêses que não fôssem casados, artistas, fabris, capitalistas de mais de dois contos de réis e que não tivessem inflû̂ncia no comércio; c) que lhes fôsse assegurado pelo "Govêrno que nunca julgaria criminoso aquêle ato" por êles praticado (93). A Sociedade desejando ver a pacificação, aconselhou o Govêrno a aceitar estas condições.

"O Conselho acedeu a que fôssem desarmados os portuguêses, contanto que tôda a gente reunida na Fortaleza ras Cinco Pontas depuzesse igualmente as armas, que deviam ser entregues ao Juiz de Paz de Santo Antonio. Também assentiu na deportação dos portuguêses que não gozassem dos foros de cidadão brasileiro e estivessem nas circunstâncias indicadas pelos sediciosos; e prometeu não persegui-los e levar súplicas ao Govêrno supremo para serem presentes à Assembléia Geral a fim de nunca ser julgado criminoso aquêle ato", informa $O$ Olindense.

A esta altura, o Govêrno se via animado com ofícios recebidos do interior hipotecando solidariedade à sua causa e até convidando-o para se estabelecer em Ipojuca, caso a capital fôsse ccupada (94). Resolveu tomar a ofensiva. Então estava clara a situração precária dos rebeldes, ilhados na Fortaleza, sem apôio dả população e desprovidos de abastecimentos. Em situação de desespêro os rebeldes passaram a hostilizar as patrulhas governistas que se achavam nas imediações da Fortaleza e a arrombar casas (95) forçando o Presidente a ordenar ao Comandante das Armas, em ofício, no qual salientava ter esgotado os meios pacíficos e. até ter aceito algumas exigências dos rebeldes, mas como os mesmos não cedessem, resolvera agir, ordenando que êle reunisse as fôrças existentes na Fortaleza do Brum (em sua imensa maioria estudontes do Curso Jurídico), e com as que se achavam no Bairro do Recife, sob o comardo do Intendente de Marinha - reunidas na rnite do dia 17 (96) - e da Boa Vista, sob o comando do Juiz de P'az da Freguesia, fôsse atacar a Fortaleza procurando antes perša-

(93). - Idem, de 1.0 de dezembro de 1831

(94). - Idem, de 1.0 de dezembro de 1831 .

(95). - Idem, de 1.0 de dezembro de 1831

(96). - Idem, de 1.0 de dezembro de 1831 . 
dí-los a rendição (97). A irresolução dominou as atitudes do presidente em todos os momentos da crise, mesmo quando, tendo reunido fôrças, dominava completamente os acontecimentos e não apenas no início, quando se viu com tropa insuficiente para a luta, como informou à Regência em seu suscinto relatório. Ele com tôda razão, afirmou o Carapuceiro não queria comprometer-se

"deixando-se levar pelos acontecimentos que poderia ter encaminhado. Assim, a 18, quando o ataque à Fortaleza já estava determinado e algumas pessoas já se retiravam da mesma, recomendava aos piquetes que não facam fogo "as patrulhas e vedetas da gente das Cinco Pontas, sem que sejam primeiramente provocados por ellas" (98) .

E tal ordem era rigorosamente cumprida uma vez que o In tendente de Marinha informava ao Presidente

"não se ter feito fogo sem que primeiramente sejamos atendidos, e até agora mesmo elles tem feito fogo e eu tenho dado ordem de não corresponder sem os alcançar em número, a fim delles gastarem o cartuxame inutilmente" (99).

Assim a falta de agressividade dos rebeldes que, no inícic, quando o Govêrno não dispunha de fôrças para a luta, não t:veram coragem de abandonar os muros protetores das Cinco Pontas e tomar a iniciativa ocupando as ruas da cidade, os perdev, apesar da irresolução e fraqueza das autoridades. Passado o momento de indecisão - dias 16 e 17 - o govêrno pôde reunir fôrças para tomar a ofensiva a 18 , ficando a revolução fracassada desde o momento que passou à defensiva e confiou nos muros protetores das Cinco Pontas. A opinião pública, o povo, que deu fôrça ao govêtno poderia ter apoiado os rebeldes se êles tivessem tomado a ofensiva a 16, explorando o ódio então existente aos portuguêses e a atitude dúbia do govêrno. A opinião pública é fàcilmente influenciável pela facção vitoriosa e a inatividade dos sediciosos lançoua aos braços do Govêrno que, dispondo de maiores recursns, dominou a situeção e venceu, apesar de sua indecisão.

Os rebeldes circunscritos à Fortaleza e temendo um ataque do Govêrno, começaram a abandoná-la, chegando a ponto de a 19 estar hasteada uma bandeira branca, não usando as armas de que dispunham contra os sitiantes. Ainda neste dia, o Presidente orde-

(97). - Idem, de 1.0 de dezembro de 1831 .

(98). - Idem, de 1.0 de dezembro de 1831 .

(99). - Idem, de 1.0 de dezembro de 1831 . 
nou ao Comandante das Armas que ocupasse a Fortaleza, cvitan-, do manifestações de triúnfo, para que não se derramasse sangue (100). Assim, vendo que o govêrno já dispunha do apôio da população da cidade, os rebeldes na madrugada dêste dia, ahendonaram as Cinco Pontas, que foi ocupada sem luta, sendo aprisionados nela os dois chefes da sedição: Capitão Antônio Afonso Viana e Tenente João Machado Magalhães. Terminava assim a luta, com pálida vitória da legalidade, passando a ser feita a devassa para apurar as culpas dos vários implicados.

No processo da Novembrada assistiríamos nova falha do Govêrno a provocar novas e sérias discussões pela imprensa. Vencidas as duas rebelióes extremadas, os portuguêses e os seus aliadis absolutistas viam aumentar a influência na província procurando comprometer todos os que não lhes eram simpáticos. Os moderados, temendo modificações revolucionárias, iam cada vez mais se afastando dos federalistas, como se êles tivessem culpa das mesmas e aproximando-se dos seus antigos inimigos. A influência litsitana chegou a tal ponto e não devemos esquecer que os portuguêses dominavam o comércio do Recife, que em 6 de dezembro de 1831, o Diário de Pernambuco publicava circular da Regência chamando a atenção para o fato de haver ainda, na província, pcstos de importância, em mãos de portuguêses que, em 1822, lutaram contra a independência do Brasil. Estes mobilizavam um exército de falsas testemunhas que implicava gente inocnnte na Novembrada e promoviam forte perseguição aos elementos nouco simpáticos ao govêrno, tomando esta sedição como pretexto. $O$ Coronel Francisco Jacinto, impassivel, sem procurar orientar os rumos da devassa, assistiu a êstes fatos como assistira à revolta (Diário de Pernambuco de 17 de dezembro de 1831) e até havia quem denunciasse os seus inimigos pessoais para se vingar die ofensas anteriores, como salientava êste jornal. Assim o Govêrno perseguiu os seus inimigos. Finalmente já em 15 de dezembro, um mês após os iutuosos acontecimentos, era enviado ao Ministro do Império a relação dos pronunciados no sumário a que se procedcu devido à Novembrada, na qual, além dos dois cabeças antes ci tados, figuravam o Sargento Francisco de Andrade Lima, o Tenen te Francisco Vitor de Melo e Albuquerque, o Capitão Franriszo José de Carvalho, o Major Francisco Antônio Pereira dos Santos, José Joaquim de Almeida, Antônio Joaquim de Andrade Brederode, Francisco Alves de Melo, Antônio de Sousa Nunes e José Felix 
de Sousa (101). A Novembrada terminou sem nem um morto e com apenas 4 feridos, todos do partido dos rebeldes.

E o ano se escoaria com um formidável deficit para a província que pode ser comprovado com a leitura do discurso do Presidente, feito na abertura do Conselho Geral da Província a 1 de dezembro de 1831, transcrito no Diário do dia 5, em que êle confessava "a queda provocada pela Setembrada na renda alfandegária que se elevou a $50 \%$ " o que,

"agravão o nosso estado financeiro; afugentando da provincia os capitaes, deminuindo o consumo dos nossos produtos ruraes, circunscrevendo as transações, dificultando os escaimbos, ferindo de morte o credito, intorpecendo a circulação, ellas produzem igualmente gravissimos danos, tanto relativamente a massa das nossas rendas, como ao total da nossa riqueza publica; damnos que parecem pouco afetar o patriotismo intolerante $e$, frenetico de alguns homens exaltados em materias politicas".

Ainda salientava o Presidente o estado "deplorável" do ensino público, a barbárie dos nossos índios - proprietários de terras que permanecem incultas - e o detestável sistema de nossas prisões. Só não acrescentou, como denunciavam os jornais de então, a ineficácia da administração, principalmente no que dizis respeito à punição dos crimes, como um dos flagelos da provínria, por conveniência, ou talvez para diminuir sua parcela de culpa no deplorável estado em que a mesma se achava.

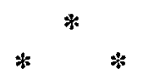

\section{CONCLUSŌES}

Além das conclusões já apresentados no texto, salientamos as que passamos a expor.

As idéias pregadas, em Pernambuco, pelas sociedades maçônicas no início do século, de tendências visivelmente. liberais e, até, republicanas, provocaram na província uma série de revo'uções que levavam a mesma a uma atitude de desconfiança contra a casa de Bragança, quer na pessoa de D. João VI, em 1817, quer na de D. Pedro I na guerra da Independência e na Confederação do Equador, que levariam, se vitoriosas ao desmembramento do

(101). - Mss. da Biblioteca Pública do Estado de Pernambuco. 
Império. Principalmente, a última, era uma reação à tenrị̂̂ncia unitarista dos políticos do sul, sobretudo do Imperador, que ?:Ocurava desconhecer as diferenças regionais, só reconhecidas pels primeira Constituição Republicana de 1891. A reação do Imperador foi violenta, destacando sempre para aqui autoridades de sua inteira confiança, fiéis à sua pessoa e não ao país ou à Constituição, e que aqui contavam com o apôio de elementos támbím absolutistas cu apenas desejosos de poder. Essas autoridades, naturalmente mal vistas pelos pernambucános, não puderam se manter nos cargos, ao chegar a notícia do 7 de abril, e foram denostas pelo povo em colaboração com a tropa, no motim de 6 de maio.

Logo após a vitória do movimento de 7 de abril, os moderados que se apossaram do poder, procuraram afastar dos postos chaves, os exaltados, como eram conhecidos os federalistas e republicanos, a por isto designaram para Comandante das Armas de Pernambuco, o Brigadeiro Francisco de Paula e Vasconcelos, que por sua atuação decidida naquele movimento, poderia ofuscar a atuação dos generais moderados, afastando-o da Côrte. Dando-lhe um pôsto importante, em uma província onde havia grarde número de portuguêses e de partidários do Imperador, nois vinham desde 1824 dirigindo-a como entendiam, não podrr:a t̂le recusar tal comissão. Passados alguns meses, em conseqüência da Setembrizada, ou Setembrada, como era então chamada, r?solveram afastá-lo do pôsto, sob acusação de que êle se desmoralizara por não ter evitado a mesma, mas tiveram o cuidado de determinar que êle aqui permanecesse, submetido às ordens de um oficial de 2.a linha e de patente inferior à sua, para evitar que sa Côrte êle fortalecesse o chamado partido exaltado, que era o dos adeptos da federação. Assim, primeiramente afastaram-no da Côrte para uma província distante, mas importante, tolhendo $a$ influência do mesmo nas decisões a serem tomadas na Capital, depois, quando fortalecidos no Govêrno, tiraram-lhe o comando, deixando-o no Norte, quase em disponibilidade. Assim, astutamente, impediram a atuação que poderia ser decisiva de um dos mais sinceros partidários do sistema federativo, o qual só foi adotaôn, como dissemos, com a proclamação da República em 1889.

A atuação do Govêrno, na repressão aos dois movimentos sediciosos de setembro e novembro, contou com o apôio decisivo dos estudantes do Curso Jurídico de Olinda, que participavam intensamente da vida política local, através da imprensa e das seciedades políticas. Eles participaram do movimento que provocou a deposição das autoridades absolutistas em 6 de maio, mas na Se- 
tembrizada apoiaram o govêrno lutando de armas na mão e ocupando as Fortalezas do Buraco e do Brum, guarneceram as mesmas durante meses, quando o Govêrno não dispunha de fôrças de linha para fazê-lo, e colaboraram na repressão à Novembrada. Na Setembrizada chegou a perecer um estudante e na Novembrata foi na Fortaleza do Brum, por êles guarnecida, que o Presidente Francisco de Carvalho Paes de Andrade se recolheu para firar cm maior segurança.

Muitos dos republicanos de 1817, das lutas da independência e da Confederação do Equador, por modificações de orientaçãn filosófica ou apenas por interêsse pessoal, tornaram-se monarqquistas e até inimigos da idéia de um Império Federado, alguns até absolutistas. Muitos dêles combateram a federação. Assim Francisco Paes Barreto, revolucionário de 1817, já em 1824 era shsolutista e partidário do Imperador, concordando com a dissolução. da Assembléia Constituinte, por desejar a Presidência da Provín. cia e seria em 1831 apontado como inimigo do país e das instituições, pelos sublevados de novembro. Gervársio Pires Ferreira, o republicano de 1817, o homem que em 1822 tentou impedir que Pernambuco acompanhasse a política monárquica de José Bonifácio e que por isto foi deposto, em 1831 era moderado, se colocando sempre ao lado dos que lutavam por todos os meios contra a federação, contra a autonomia das províncias. Não é den ais se recordar a guerra movida à Sociedade Federal, pela chamara $\mathrm{Pa}$ triótica Harmonizadora, na qual, acompanhado de Antônio Joaquim de Melo tinha grande influência. Francisco de Carvalho Píes de Andrade, revolucionário de 1824, irmão do líder da ConfeAleração do Equador, também no govêrno mostrou-se completamente afastado dos princípios que outrora defendia, ligando-se aus que combatiam a autonomia das províncias. Mas, nada disto é de espantar, porque o próprio Manuel de Carvalho Paes de Andráce que regressaria do exílio em dezembro de 1831, aproxirnou-se tanto dos moderados, que com êste partido governou depois a província e reprimiu violentamente a Guerra dos Cabanos. O revolu cionário de 1824, o chefe da República Confederada do Equałor, morreria calmamente como Senador do Império pela províacia da Paraíba, após participar da campanha da Maioridade. Assirn, os políticos mudaram muito, em pouco tempo.

A Setembrizada, ou Setembrada como chamavam então, foi um motim surgido como consequêencia da situação difícil por que passava a província, não só do ponto de vista político, como econômico e social, não tendo sido preparada por nenhuina das correntes políticas, como se quis posteriormente insinuar. O Presi- 
dente Pinheiro contou para a sua repressão com tôdas as fôrças da província $\epsilon$ ela foi vencida fàcilmente porque näo foi plarejada, rebentando expontâneamente em consequiência de medicas disciplinares tomadas pelo Comandante das Armas, e não encontrou um líder que a orientasse e fizesse exigências ao govêruo; não encontrou quem os preparasse para a luta com as fôrças traz:das do interior e também porque, desorganizados, passaram a saq!eear e roubar as casas comerciais, embriagando-se em sua imensa maioria, com as bebidas alcoólicas retiradas das tabernas Ass: $m$, reconhecemos que ela foi provocada indiretamente pelas difíccis condições políticás, econômicas e sociais então dominantes, mas que não teve nenhum fim predeterminado, reduzindo-se a um simples motim, sem maiores conseqüências que os transtornos então f:ovocados.

A Novembrada foi uma quartelada, sem apôio dos federalistas da província, mas apenas das pessoas mais exaltadas e incon. seqüentes e que, apesar da situação difícil do Govêrno, fracassou pela dispersão quando podia ter arrancado ao mesmo algurras roncessões, se seus chefes fôssem mais enérgicos e tivessem levado a luta às ruas da cidade, nos primeiros momentos do levante, nos dias 16 e 17, quando as atitudes do govêrno denotavam uma tre menda vacilação.

Finalmente, o ano de 1831 foi um dos mais agitados da vida pernambucana e disto resultou a péssima situação em que estava a província quando chegou ao fim, o que é constatado pelas palavras do próprio Presidente na abertura do Conselho Geral da Província. 